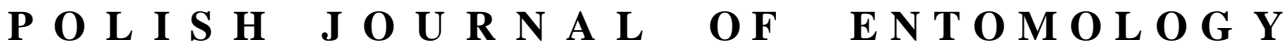

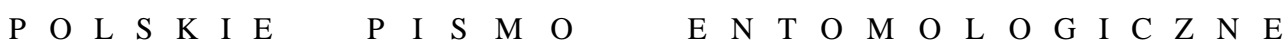

VOL. 86: 9-38

Lublin

31 March 2017

DOI: $10.1515 /$ pjen-2017-0002

\section{Fifty years of scientific research by Professor Józef BANASZaK, the honorary member of the Polish Entomological Society, on the $\mathbf{7 0}^{\text {th }}$ anniversary of his birth}

\author{
WERONIKA BANASZAK-CIBICKA* \\ Institute of Zoology, Poznań University of Life Sciences, Wojska Polskiego 71C, 60-625 \\ Poznań, Poland
}

On 28 March 2016, an observation of an early bumblebee (Bombus pratorum (LINNAEUS, 1761)) by Professor Józef BANASZAK, eminent expert on bees and ecology, began his $51^{\text {st }}$ year of research on bees.

Józef BANASZAK was born on 19 March 1947 in Lednogóra near Gniezno, and even in childhood came to be fascinated by wildlife. His particular interest in insects was inspired by a book by Professor Jan KARPIŃSKI, entitled In the Land of Wonders of Jean Henri FABRE (in Polish: W krainie dziwów Jean Henri FABRE'a). Thanks to this book, he learned about the work of the $19^{\text {th }}$-century naturalist, who was one of the first to study not only the biology but also the behaviour of insects. In secondary school, with an insect net made from an old curtain, Józef caught his first specimens: butterflies and beetles. He finished school in 1965 and entered the Faculty of Biology at Adam Mickiewicz University, Poznań, Poland. His interest in bees began in his first year, in the spring of 1966, after he read a short note on the digger bee, Anthophora plagiata (ILLIGER, 1806), which builds its nests in loess and clay escarpments as well as in clay buildings. The author, Zygmunt PNIEWSKI, noted that the species is very rare, but the young biologist, based on a photo illustrating the short note, discovered that the bee was nesting in a wall of his family house! This discovery of a new locality of $A$. plagiata and the opportunity to write his first publication about his discovery resulted in his later focus on bees instead of coleopterans, which he had earlier favoured. He then got in touch with the author of the short note, received from him his first entomological pins and an insect storage box, and learned the basics of insect preservation.

\footnotetext{
*Corresponding author: banaszak@up.poznan.pl
} 
The first bees caught by the future professor are labelled with the date 24 April 1966. That spring was the beginning of his more than 50 years of research on bees.

In 1970, after graduating with an MSc in Biology (specializing in Zoology), he was employed as an assistant (and from 1973 as a senior assistant) at the Institute of Veterinary Medicine, Department of Research on Diseases of Useful Insects, in Swarzędz near Poznań. In view of the types of research conducted at the Institute, related to the honey bee and its diseases, he investigated the diversity and role of the fauna accompanying honey bee families. But he did not give up his main interest, and continued research on the fauna of wild bees in several regions of Poland: Wielkopolska, western Pomerania, the Vistula valley, and the Bieszczady Mts. In 1975, he earned a PhD in Biology (specializing in Zoology) and was employed as an assistant professor at the Department of Agricultural and Forest Biology of the Polish Academy of Sciences in Poznan (formerly Department of Agricultural Biology of the Institute of Ecology). There he conducted research on benthic fauna in various types of water bodies and watercourses in the agricultural landscape, with particular reference to dipteran larvae of the family Chironomidae. That research allowed him to describe the strategy of colonization of watercourses and standing waters by benthic organisms, and to show that running waters increase the biodiversity of the agricultural landscape to a greater extent than small bodies of standing water.

In that period, he also started to study faunistic changes and resources, and the regularity of occurrence of pollinating insects in the landscape. These were the first largescale investigations of species diversity and density of pollinating insects in Poland. For the first time, bee densities were assessed in natural habitats, not only in crop fields. The main objective was to improve the understanding of Poland's fauna. The research projects initiated in that period provided rich data on the contemporary bee resources, especially in the Wielkopolska-Kujawy Lowland, the Masovian Lowland, the Polish coast of the Baltic Sea, the lower Vistula valley, the south-eastern part of the country, and central Poland. Bee studies were also conducted in many national parks (Wolin NP, Wigry NP, Wielkopolska NP, Kampinos NP, Narew NP, Bieszczady NP, "Bory Tucholskie" NP, Drawa NP and Białowieża NP) and landscape parks (Masurian LP, Vistula LP, General Dezydery Chłapowski LP and Lednica LP). The results of those studies and of reports by other authors were summarized in a catalogue of bee species (Apiformes) of Poland published in 1991 and updated in 2000 and 2004. All this enabled him to compile a red list of Apiformes of Poland in 1992 (updated in 2002), and to select and describe threatened species of Aculeata (Apiformes, Scolia, Parnopes) in the Polish Red Data Book of Animals (2004). 


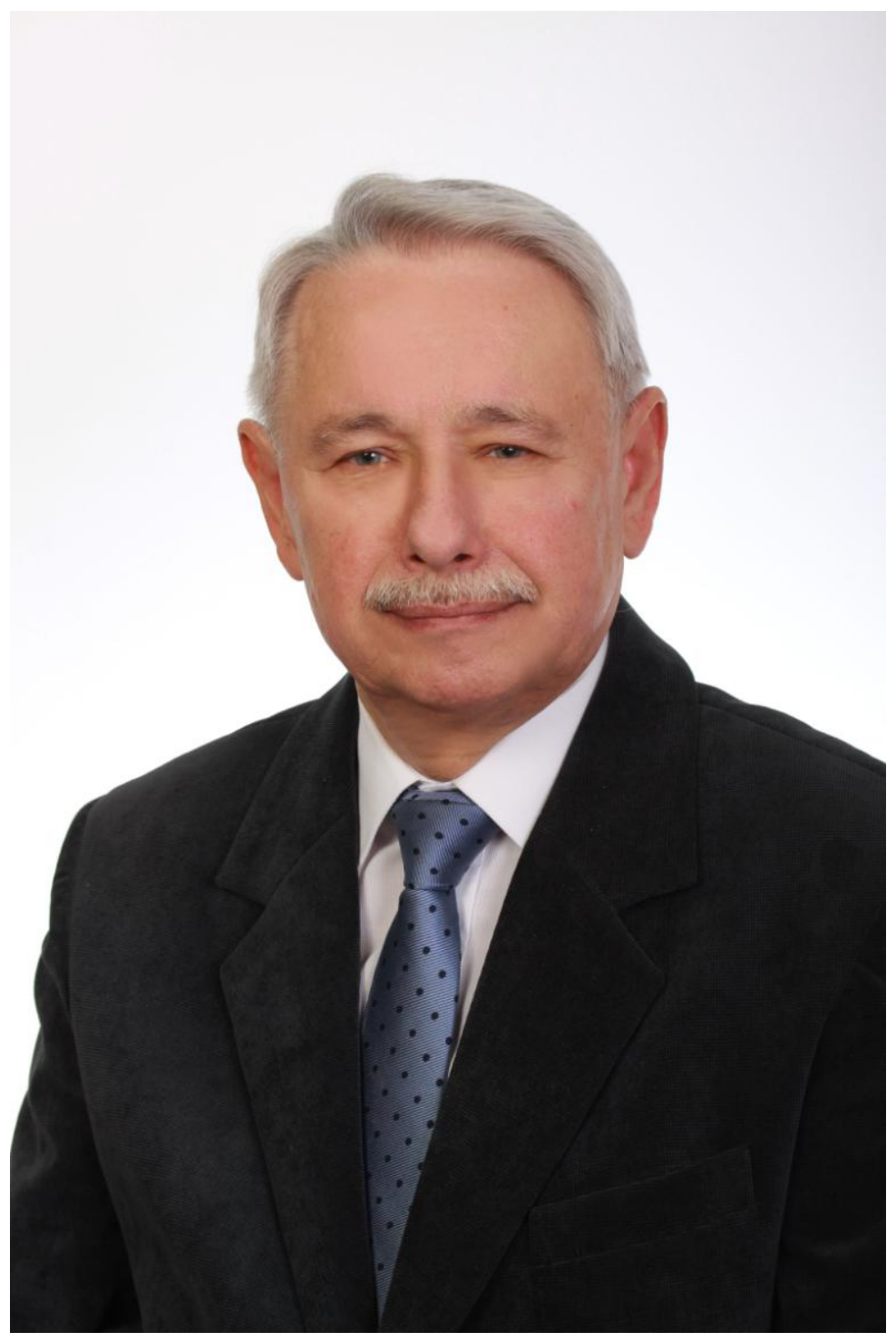

Phot. 1. Prof. Józef BANASZAK (Phot. FOTO-RAMA Bydgoszcz).

The Professor's research into bee ecology on a landscape scale also enabled him to develop a general strategy to protect pollinating insects in the agricultural landscape. The strategy emphasizes the significance of a mosaic of diverse landscape for the presence and proper functioning of those animals. The results of his studies were highly valued and are still cited in the international literature. 
The monitoring initiated in 1975 , serving to assess changes in the fauna of pollinating insects in various habitat types, is still being continued. It is conducted in 10-year cycles on permanent plots with well-defined plant cover. The Professor's important achievements also include developing and publishing a new method for the quick and precise assessment of densities of pollinating insects in various types of plant communities. This method makes it possible to estimate the natural resources of bees and compare quantitative changes taking place in various types of landscape (1980). It has been employed by entomologists not only in Poland but also in other countries of Europe.

In parallel to his studies of Polish fauna, Professor BANASZAK has also assessed bee resources in other parts of Europe. He has undertaken many research expeditions, for example, to Romania $(1984,1985)$, Bulgaria $(1986,1988,1990)$, Lower Saxony and the Frisian Islands in Germany (1987), Belgium, Provence, Corsica, and the Pyrenees in southern France (1993), as well as Sardinia in Italy (2000).

In 1989, he was employed as an assistant professor and head of the Department of Environmental Protection within the Chair of Environmental Protection and Physical Education at Kazimierz Wielki University in Bydgoszcz (known then as a Teachers' College and later as the Bydgoszcz Academy). In 1990 he was employed there as an associate professor, and in 1991 as a full professor in the field of natural sciences. At that time he became the head of the Chair of Environmental Protection and Physical Education, later transformed by him into the Chair of Biology and Environmental Protection.

In the early 1990s, the Professor initiated and coordinated the cooperation of an informal research group, known as an Interdisciplinary Landscape Ecology Research Team. The team investigated the role of forest islands in the agricultural landscape. Several years of studies by specialists in various fields - geomorphology, soil science, botany, phytosociology, entomology, acarology, malacology, arachnology, herpetology, and mammalogy - formed a basis for a better understanding of the mechanisms of how refuge habitats and wildlife corridors function in an agricultural landscape. The extremely interesting results of the studies were presented at international and national conferences and described in many articles. The outcome of this project is summarized in a monograph that he edited, entitled Ecology of Forest Islands, which was published both in Polish (1998) and in English (2000). In 2002, it was followed by another monograph edited by the Professor, entitled Habitat Islands: Biodiversity and Attempts at Typology.

In the late 1990s, Professor BANASZAK began intensive cooperation with distinguished experts from other European research centres. The cooperation resulted in the publication of books on bee taxonomy and systematics: monographs on the European Megachilidae, Halictidae, and Andreninae of the Palaearctic (two volumes), and two keys to the identification of the Megachilidae and Halictidae in the series "Keys to the Identification of 
Insects in Poland". Another important publication is the book Changes in Fauna of Wild Bees in Europe (BANASZAK 1995).

In 2010, the Professor published the book Bees and Forest. This represented a completely new direction of research, investigating the unusual phenomenon of the introduction of honey bees to forests in the Middle Ages, followed by their transfer to other habitats in the $18^{\text {th }}$ century. This was a kind of biological experiment: the transfer of bees from forests to apiaries near houses, to the open habitats of arable fields. Simultaneously, the ecological niches of honey bees in forests were occupied by other pollinating insects, which markedly affected the forest ecosystem.

During his 50 years of scientific research, Professor J. BANASZAK made a substantial contribution to knowledge about Polish and European bee fauna. He has authored more than 350 publications, including around 120 original reference works and scientific articles, mostly in the field of entomology and ecology, in Polish and foreign journals. He is also the author, co-author or editor of 51 books. His work has earned him an important position in the international scientific community. He has been cited both in Poland and abroad by renowned researchers. Moreover, two species have been named after him: Trichouropoda banaszaki WiŚNIEWSKI \& HIRSCHMANN, 1988 (Acari) and Sphecodes banaszaki NOBILE $\&$ TURRISI, 2004 (Apiformes, Hymenoptera).

When considering the activity of Professor BANASZAK over the past 50 years, his organizational skills should also be taken into account. As Rector of the Teachers' College (1996-1999) he succeeded in transforming it into the Kazimierz Wielki Academy of Bydgoszcz. Thus he made a significant contribution to its later transformation into Kazimierz Wielki University. He also initiated the creation of the Institute of Biology and Environmental Protection, as well as new courses of studies: Biology (1993) and Environmental Protection (2007). Besides this, he was involved in the organization of the Museum of Diplomacy and Polish Exiles (1999). In 2005-2010 he was the Editor-in-Chief of the Polish Journal of Entomology. The Professor is also an honorary member of the Polish Entomological Society. Moreover, in 2002 he established the Wierzenica Professors' Club, which is an informal forum for discussions between scientists and other creators. As a result of the meetings and discussions of scientists, humanists, and artists, several books edited by J. BANASZAK have been published in the Library of the Wierzenica Professors' Club. He is also the author of several volumes of poems, memoirs, and diaries.

Finally, for me personally, Professor Józef BANASZAK is obviously my Dad, who often took me and my brother Dominik with him on his field trips. We would play in the meadow while he was catching bees, which later - arranged in even rows - filled insect storage boxes and occupied cabinets in our home. It was my Dad who bought me my first insect net, and I will never forget the first insect I caught in it. Later on, when I was writing my MSc thesis on the bee from which the whole story began (Anthophora plagiata), my Father 
also became my tutor and introduced me into the world of bees, this extremely interesting group of insects of such great importance to humankind.

\section{LIST OF PUBLICATIONS}

\section{ENTOMOLOGY AND OTHER NATURAL SCIENCES}

\section{Scientific monographs}

1. Banaszak J. 1980. The Catalogue of the Polish fauna. XXVI, 3: Cuckoo Wasps. Chrysididae. PWN, Warszawa, 52 pp. (in Polish)

2. BANASZAK J. 1987. Bees and plant pollination. PWRiL, Poznań, 255 pp. (in Polish)

3. BANASZAK J. (ed.) 1992. Natural resources of wild bees in Poland. Pedagogical University in Bydgoszcz, Bydgoszcz, 174 pp.

4. BANASZAK J. 1993. Bumblebees of Poland. Wydawnictwo Uczelniane Wyższej Szkoły Pedagogicznej w Bydgoszczy, Bydgoszcz, 158 pp. (in Polish)

5. BANASZAK J. (ed.) 1993. Ecological landscape. Wydawnictwo Uczelniane Wyższej Szkoły Pedagogicznej w Bydgoszczy, Bydgoszcz, 456 pp.

6. BANASZAK J. 1993. Ecology of bees. Wydawnictwio Naukowe PWN, Warszawa - Poznań, 263 pp. (in Polish)

7. BANASZAK J. (ed.) 1995. Changes in fauna of wild bees in Europe. Pedagogical University in Bydgoszcz, Bydgoszcz, 220 pp.

8. BANASZAK J. (ed.) 1996. Natural environment of Bydgoszcz. Wydawnictwo Tanan, Bydgoszcz, 256 pp. (in Polish)

9. Banaszak J. Romasenko L. 1998. Megachilid Bees of Europe (Hymenoptera, Apoidea, Megachilidae). Pedagogical University of Bydgoszcz, Bydgoszcz, 239 pp.

10. BANASZAK J. (ed.). 1998. Ecology of forest island. Wydawnictwo Uczelniane Wyższej Szkoły Pedagogicznej w Bydgoszczy, Bydgoszcz, 326 pp. (in Polish)

11. BANASZAK J. TobolsKi K. (eds.) 1998. Bory Tucholskie National Park. The recognition of nature against the background of the Tuchola Pinewoods complex. $2^{\text {nd }}$ edition. Wydawnictwo Uczelniane Wyższej Szkoły Pedagogicznej w Bydgoszczy, Bydgoszcz, 486 pp. (in Polish)

12. BAnASZAK J. (ed.) 2000. Ecology of Forest Island. Bydgoszcz University Press, Bydgoszcz, 313 pp.

13. Pesenko Yu.A., Banaszak J., Radchenko V.G., Cierzniak T. 2000. Bees of the family Halictidae (excluding Sphecodes) of Poland: taxonomy, ecology, bionomics. Wydawnictwo Uczelniane Wyższej Szkoły Pedagogicznej w Bydgoszczy, Bydgoszcz, 348 pp.

14. Banaszak. J., Romasenko L., Cierzniak T. 2001. Keys to identification of Polish insects, Part XXIV, issue 68f, Subfamily Megachilinae. Polskie Towarzystwo Entomologiczne, Toruń 156 pp. (in Polish)

15. Banaszak J. Romasenko L. 2001. Megachilid Bees of Europe. Second Edition. Bydgoszcz University of Kazimierz Wielki, Bydgoszcz, 239 pp.

16. BANASZAK J. (ed.) 2002. Habitat islands. Biodiversity and typology. Wydawnctwo Akademii Bydgoskiej im. Kazimierza Wielkiego, Bydgoszcz, 302 pp. (in Polish) 
17. BAnASZAK J. Tobolski K. (eds.) 2002. National Park „Bory Tucholskie” against the background of the biosphere reserve. Wydawnictwo Homini, Charzykowy, 360 pp. (in Polish)

18. GŁowaciński Z. (ed.), Banaszak J., Bernard R., BŁaszak C., Buczyński P., Buszko J., Bystrowski C., CZechowski W., Drohojowska J., Dyduch-Falniowska A., FiaŁkowski W., GŁowaciński Z., Gorczyca J., Huflejt T., Jażdżewska T., JażdŻewski K., Klasa A., KŁonowska-Olejnik M., Krzemiński W., Kubisz D., Liana A., Łabędzki A., Mazur M., Mikolajczyk W., Nowacki J., Palaczyk A., PawŁowski J., Piechocki A., Rafalski J., Riedel A., SAwoniewicz J., Skibińska E., Soszyński B., Sowa R., Staręga W., SzczęSny B., SzWedo J., ToŃCZYK G., WęGierek P., WiedeŃSKA J., WikToR A., WiŚNiOWSKi B., WOJCIECHOWSKi W., ZAJĄC K. 2002. Red list of threatened Animals in Poland. Suplement. Wydawnictwo Instytutu Ochrony Przyrody PAN, Kraków, 74 pp. (in Polish)

19. Pesenko Yu.A., Banaszak J., Cierzniak T. 2002. Keys to identification of Polish insects, Part XXIV, Hymenoptera, Apidae, Issue 68b, Subfamily Halictinae. Polskie Towarzystwo Entomologiczne, Torun, 302 pp. (in Polish)

20. BANASZAK J. (ed.) 2003. The Wielkopolska stepping - fifty years later. Wydawnictwo Akademii Bydgoskiej im. Kazimierza Wielkiego, Bydgoszcz, 266 pp. (in Polish)

21. Romasenko L., Banaszak J., Kozhevnikova V. 2003. Type specimens of bees of Andrenidae and Colletidae from Schmalhausen Institute of Zoology in Kiev. Wydawnictwo Akademii Bydgoskiej im. Kazimierza Wielkiego, Bydgoszcz, 85 pp.

22. BANASZAK J. (ed.). 2004. Natural World of Bydgoszcz. Wydawnictwo Akademii Bydgoskiej im. Kazimierza Wielkiego, Bydgoszcz, 223 pp. (in Polish)

23. Osytshnum A.Z., Romasenko L., Banaszak J., Cierzniak T. 2005. Andreninae of the Central and Eastern Palearctic. Part. 1. Polish Entomological Society, Poznań - Bydgoszcz, 235 pp.

24. BAnAsZaK J., Tobolski K. (eds.) 2006. National Park „Bory Tucholskie” at the beginning of a New decade. Wydawnictwo Uniwersytetu Kazimierza Wielkiego, Bydgoszcz, 320 pp. (in Polish)

25. BANASZAK J., RATYŃSKa H. (eds.) 2008. Natural world of palace park in Lubostroń. Oficyna Wydawnicza Branta, Bydgoszcz, 180 pp. (in Polish)

26. Osytshnjuk A Z., Romasenko L., Banaszak J., Motyka E. 2008. Andreninae of the Central and Eastern Palaearctic. Part 2. Polish Entomological Society, Poznań - Bydgoszcz, 233 pp.

27. BANASZAK J. 2010. Bees and forest. The honey bee versus the postglacial history of forests in Poland. Wydawnictwo Alegoria, Wydawnictwo Wilczyska, Warszawa, 102 pp. (in Polish)

\section{Chapters in scientific monographs}

28. BANASZAK J. 1984. Ecological conditions and threats of Swarzędz Lake. [in:] Informator: Ochrona środowiska Jeziora Swarzędzkiego. Naczelnik Miasta i Gminy Swarzędz, Swarzędz, 88-102. (in Polish)

29. BANASZAK J. 1984. Pattern of distribution of Apoidea in agricultural landscape. [in:] Compte rendu du V Symposium International sur la pollinisation. Versailles, 27-30 septembre 1983. INRA Publ. (Les Colloques de l'INRA 21). Institut national de la recherche agronomique, Paris, 223-227.

30. BANASZAK J. 1984. The importance of planned D. Chłapowski Agroecological Landscape Park for land management. [in:] L. RYSZKOWSKI, K. ZIMNIEWICZ (eds.). Stan i kształtowanie wartości krajobrazowych na Ziemi Kościańskiej. Towarzystwo Miłośników Ziemi Kościańskiej, Kościan, 78-96. (in Polish) 
31. BANASZAK J. 1989. Investigations on natural resources of pollinators. [in:] Z. STASZEWSKI, A. UtRata (eds.). Unconventional methods in lucerne breeding. Proceedings Medicago sativa Working Group Meeting, Radzików, Sept. 12-17, 1988. Institute Extention Service, Radzików, 27-29.

32. Wójtowski F., Wilkaniec Z., Banaszak J., Cierzniak T., Biliński M., Pawlikowski T. 1990. The recognition of natural resources and possibilities of increasing abundance of wild bees in agricultural landscape. [in:] E. BERNADZKI (ed.). Charakterystyki ekologiczne wybranych elementów krajobrazów rolniczych. Wydawnictwo SGGW-AR, Warszawa, 155-171. (in Polish)

33. BANASZAK J. 1992. Bees Apoidea. [in:] Z. GŁOWACIŃSKi (ed.). Red list of threatened and endangered animals in Poland. Zakład Ochrony Przyrody i Zasobów Naturalnych PAN, Kraków, 49-58. (in Polish)

34. BANASZAK J. 1992. Natural resources of wild bees in Poland as compared to other European countries. [in:] J. BANASZAK (ed.). Natural resources of wild bees in Poland. Pedagogical University in Bydgoszcz, Bydgoszcz, 17-26.

35. BanaszaK J., KrzysztofiaK A. 1992. Communities of bees in the forests of Poland. [in:] J. BANASZAK (ed.). Natural resources of wild bees in Poland. Pedagogical University in Bydgoszcz, Bydgoszcz, 35-40.

36. BanaszaK J., CierzniaK T. 1992. Studies on Apoidea resources in the agricultural landscape of Poland. [in:] J. BANASZAK (ed.). Natural resources of wild bees in Poland. Pedagogical University in Bydgoszcz, Bydgoszcz, 49-78.

37. BanaszaK J. 1992. Bees of urban environments in Poland. [in:] J. BanaszaK (ed.). Natural resources of wild bees in Poland. Pedagogical University in Bydgoszcz, Bydgoszcz, 101-107.

38. BANASZAK J. 1993. Landscape ecology as a subject of research and education. [in:] J. BANASZAK (ed.). Krajobraz ekologiczny. Wydawnictwo Uczelniane Wyższej Szkoły Pedagogicznej w Bydgoszczy, Bydgoszcz, 7-15. (in Polish)

39. BANASZAK J., KASPRZAK K. 1993. The landscape in environmental sciences. [in:] J. BANASZAK (ed.). Krajobraz ekologiczny. Wydawnictwo Uczelniane Wyższej Szkoły Pedagogicznej w Bydgoszczy, Bydgoszcz, 17-51. (in Polish)

40. BANASZAK J., CiERzNiaK T. 1993. Research on pollinating insects on the landscape level. [in:] J. BANASZAK (ed.). Krajobraz ekologiczny. Wydawnictwo Uczelniane Wyższej Szkoły Pedagogicznej w Bydgoszczy, Bydgoszcz, 199-215. (in Polish)

41. BANASZAK J. 1995. Ecosystem-ecological landscape-nature conservation. [in:] Materiały Konferencji "Edukacja - ochrona przyrody - przemysł", ATR, SNPPiT, WSP w Bydgoszczy. Wyższa Szkołą Pedagogiczna w Bydgoszczy, Bydgoszcz 19-21 IX 1992, 9-21, 22-29. (in Polish)

42. BANASZAK J. 1995. Natural resources of wild bees in Poland and an attempt at estimation of their changes. [in:] J. BANASZAK (ed.). Changes in fauna of wild bees in Europe. Pedagogical University in Bydgoszcz, Bydgoszcz, 11-25.

43. Banaszak J., Cierzniak T. Kaczmarek S., Kozacki L., Manole T., Pilacińska B., Ratyńska H., SZWED W., WIŚNIEWSKI H. 1995. Preliminary investigations on biocenoses of forest islands in an agricultural landscape. [in:] A. Richling, E. MALINOWSKA, J. LeChNiO (eds.). "Jakość krajobrazu - jakość życia". Materiały konferencji, Płock, 6-8.10.1994. Uniwersytet Warszawski, Warszawa, 9-19. (in Polish)

44. Rasmont P., Ebmer A., Banaszak J., Zanden van der G. 1995. Hymenoptera Apoidea Gallica. Liste taxonomique des abeilles de France, de Belgiue, de Suisse et du Grand-Duche de Luxembourg. Butlletin de la Société entomologique de France 100(1): 1-98. 
45. BANASZAK J. 1996. Thoughts after reading current biology school books. [in:] H. WIŚNIEWSKI (ed.). Nowatorskie rozwiązania w zakresie programów nauczania biologii i ich dydaktycznej obudowy. Wydawnictwo Uczelniane Wyższej Szkoły Pedagogicznej w Budgoszczy, Bydgoszcz, 187-191. (in Polish)

46. BANASZAK J. 1996. Urban fauna. [in:] J. BANASZAK (ed.). Środowisko przyrodnicze Bydgoszczy. Wydawnictwo Tanan, Bydgoszcz, 115-133. (in Polish)

47. BANASZAK J. 1996. Ecological bases of conservation of wild bees. [in:] A. MATHESON, S.L. Buchmann, C. O'Toole, I.J. Wiliams (ed.). The Conservation of Bees. Academic Press, London, 55-62.

48. Banaszak J., Cierzniak T., Kozacki L., Ratyńska H., Szwed W. 1996. Investigation on the ecology of forest islands in the "Puszcza Zielonka" Landscape Park. [in:] M. KISTOwSKI (ed.) Badania ekologiczno-krajobrazowe na obszarach chronionych. Uniwersytet Gdański, Gdańsk, 46-54. (in Polish)

49. BANASZAK J. 1998. Ecology and environment conservation, what is and what is not ecology. [in:] A. SygiT (ed.). Ochrona środowiska na przykładzie gminy Jeziora Wielkie. Urząd Gminy w Jeziorach Wielkich k. Bydgoszczy, Jeziora Wielkie, 56-59. (in Polish)

50. BANASZAK J. 1998. What is and what is not ecology? [in:] A. PAPUZIŃSKI (ed.). Decentralizacja - regionalizacja - ekologia. Wydawnictwo Uczelniane Wyższej Szkoły Pedagogicznej w Bydgoszczy, Bydgoszcz, 14-16. (in Polish)

51. BANASZAK J. CierzniaK T. 1998. Pollinating insects - Apoidea. [in:] J. BAnAsZaK (ed.). Ekologia wysp leśnych. Wydawnictwo Uczelniane Wyższej Szkoły Pedagogicznej w Bydgoszczy, Bydgoszcz, 13-139. (in Polish)

52. BANASZAK J. 1998. From the research on fauna and ecology of cities. [in:] T. BARCZAK, P INDYKIEWICZ (eds.). Urban Fauna. Wydawnictwo Akademii Techniczno-Rolniczej, Bydgoszcz, 21-45. (in Polish)

53. BANASZAK J. 1998. Bees of urban environment [in:] T. BARCZAK, P. INDYKIEWICZ (eds.). Urban Fauna. Wydawnictwo Akademii Techniczno-Rolniczej, Bydgoszcz, 57-62. (in Polish)

54. BANASZAK J., Cierzniak T. 1997. Spatial and temporal changes in diversity and density of bees (Apoidea) in the deciduous forests of Poland. [in:] V.E. KiPIATKov (ed.). Proceedings of the International Colloquia on Social Insects, vol. 3-4. Russian Language Section of the International Union for the Study of Social Insects, St. Petersburg, 89-99.

55. BANASZAK J. 2000. Effect of habitat heterogenity on the diversity and density of pollinating insects. [in:] B. Еквом, M.E. IRwIN, Y. RobeRT (eds.). Interchanges of Insects between Agricultural and Surrounding Landscapes. Kluwer Academic Publishers, Dordrecht - Boston London, 123-140.

56. Banaszak J., Cierzniak T. 2000. Pollinating insects (Apoidea). [in:] J. Banaszak (ed.). Ecology of Forest Islands. Bydgoszcz University Press, Bydgoszcz, 107-134.

57. BANASZAK J. 2001. Condition and the need of zoological research in the area of proposed Pałucki Landscape Park. [in:] E. KRASICKA-KorCzyńsKA E. (ed.). Przyroda, krajobraz, kultura Pałuk, Stowarzyszenie Ekologiczne w Barcinie, Barcin, 133-154. (in Polish)

58. BANASZAK J., WENDZONKA J. 2002. Introductory results of research on dominance structure of insects of "Bory Tucholskie"National Park. [in:] J. BANASZAK, K. TOBOLSKI(eds.). Park Narodowy "Bory Tucholskie" na tle rezerwatu biosfery. Wydawnictwo Homini, Charzykowy, 107-112. (in Polish) 
59. Banaszak J., Kriger R., Wendzonka R. 2002. A review of research on insects and spiders of Tuchola Pinewoods. [in:] J. BANASZAK, K. ToBolski (eds.). Park Narodowy "Bory Tucholskie" na tle rezerwatu biosfery. Wydawnictwo Homini, Charzykowy, 229-242. (in Polish)

60. BANASZAK J. 2002. Opening remarks to the discussion about the ecology and significance of environmental islands. [in:] J. BANASZAK (ed.). Wyspy środowiskowe. Bioróżnorodność i próby typologii. Wydawnictwo Akademii Bydgoskiej im. Kazimierza Wielkiego, Bydgoszcz, 9-11. (in Polish)

61. BANASZAK J., CiERZniaK T. 2002. Environmental islands in the agricultural landscape as refuges for pollinating insects - valorization attempt [in:] J. BANASZAK (ed.). Wyspy środowiskowe. Bioróżnorodność i próby typologii. Wydawnictwo Akademii Bydgoskiej im. Kazimierza Wielkiego, Bydgoszcz, 105-125. (in Polish)

62. BANASZAK J. 2002. Chrysididae. [in:] Z. GŁOWACIŃSKi (ed.). Red list of threatened animals in Poland. Wydawnictwo Instytutu Ochrony Przyrody PAN, Kraków, 54-56. (in Polish)

63. BANASZAK J. 2002. Apoidea [in:] Z. GŁOWACIŃSKi (ed.). Red list of threatened animals in Poland. Wydawnictwo Instytutu Ochrony Przyrody PAN, Kraków, 69-74. (in Polish)

64. BANASZAK J. 2002. The problem of changes in bee fauna - a question of time or scale? [in:] R. JONES (ed.). Bees without frontiers. Proceedings of the Sixth European Bee Conference, Cardiff 2002. IBRA Publications, Bristol, 109-121.

65. BANASZAK J. 2003. Introduction to the discussion about old and new environment and nature problems of Wielkopolska region. [in:] J. BANASZAK (ed.). Stepowienie Wielkopolski - pół wieku później. Wydawnictwo Akademii Bydgoskiej im. Kazimierza Wielkiego, Bydgoszcz, 9-12. (in Polish)

66. BANASZAK J. 2003. Professor Adam WodZicZKo - the author of modern concept of nature conservation and landscape ecology. [in:] J. BANASZAK (ed.). Stepowienie Wielkopolski - pół wieku później. Wydawnictwo Akademii Bydgoskiej im. Kazimierza Wielkiego, Bydgoszcz, 13-24. (in Polish)

67. BANASZAK J. 2003. The issue of changes of invertebrate fauna. The truth and myths on the example of the pollinating insects. [in:] J. BANASZAK (ed.). Stepowienie Wielkopolski - pół wieku później. Wydawnictwo Akademii Bydgoskiej im. Kazimierza Wielkiego, Bydgoszcz, 101-116. (in Polish)

68. BANASZAK J. 2004. From research on pollinating insects in Bydgoszcz (Hymenoptera, Apoidea). [in:] P. INDYKIEWICZ, T. BARCZAK (eds.). Fauna miast Europy Środkowej 21. wieku. Wydawnictwo LOGO, Bydgoszcz, 225-233. (in Polish)

69. BANASZAK J. 2004. Parnopes grandior (PAllas, 1771). [in:] Z. GŁowacińSKI, J. Nowacki (eds.). Polish Red Data Book of Animals. Invertebrates. Instytut Ochrony Przyrody PAN, Akademia Rolnicza im. Augusta Cieszkowskiego, Kraków - Poznań, 174-175. (in Polish)

70. BANASZAK J. 2004. Scolia hirta Schrank, 1781. [in:] Z. GŁOWACIŃSKI, J. NowACKI (eds.). Polish Red Data Book of Animals. Invertebrates. Instytut Ochrony Przyrody PAN, Akademia Rolnicza im. Augusta Cieszkowskiego, Kraków - Poznań, 175-176. (in Polish)

71. BANASZAK J. 2004. Chalicodoma parietina (FourCroy, 1785). [in:] Z. GŁowaciński, J. NowACKI (eds.). Polish Red Data Book of Animals. Invertebrates. Instytut Ochrony Przyrody PAN, Akademia Rolnicza im. Augusta Cieszkowskiego, Kraków - Poznań, 215-217. (in Polish)

72. BANASZAK J., CELARY W. 2004. Amegilla quadrifasciata (VILLERS, 1789). [in:] Z. GŁowACIŃSKI, J. NowACKI (eds.). Polish Red Data Book of Animals. Invertebrates. Instytut Ochrony Przyrody PAN, Akademia Rolnicza im. Augusta Cieszkowskiego, Kraków - Poznań, 218-219. (in Polish) 
73. BANASZAK J. 2004. Xylocopa valga Gerstaecker, 1872. [in:] Z. GŁOWACiŃSKi, J. Nowacki (eds.). Polish Red Data Book of Animals. Invertebrates. Instytut Ochrony Przyrody PAN, Akademia Rolnicza im. Augusta Cieszkowskiego, Kraków - Poznań, 220-221. (in Polish)

74. BANASZAK J. 2004. Xylocopa violacea (LinnAeus, 1758). [in:] Z. GŁowacińSKI, J. Nowacki (eds.). Polish Red Data Book of Animals. Invertebrates. Instytut Ochrony Przyrody PAN, Akademia Rolnicza im. Augusta Cieszkowskiego, Kraków - Poznań, 221-222. (in Polish)

75. BANASZAK J. (ed.) 2004. The city and its nature - opening remarks. [in:] J. BANASZAK (ed.). Przyroda Bydgoszczy. Wydawnictwo Akademii Bydgoskiej im. Kazimierza Wielkiego, Bydgoszcz, 7-10. (in Polish)

76. BANASZAK J. 2004. From history of zoological research in Bydgoszcz and region. [in:] J. BANASZAK (ed.). Przyroda Bydgoszczy. Wydawnictwo Akademii Bydgoskiej im. Kazimierza Wielkiego, Bydgoszcz, 73-79. (in Polish)

77. Banaszak J. 2004. A review of studies on the fauna of cities. [in:] J. BANASZAK (ed.). Przyroda Bydgoszczy. Wydawnictwo Akademii Bydgoskiej im. Kazimierza Wielkiego, Bydgoszcz, 81-108. (in Polish)

78. BanaszaK J. 2004. Bees (Apidae). [in:] W. Bogdanowicz, E. Chudzicka, J. Pilipiuk, E. SKIBIŃSKA (eds.). Fauna of Poland. Characteristics and checklist of species, vol. 1. Muzeum i Instytut Zoologii PAN, Warszawa, 346-350. (in Polish)

79. Banaszak J. 2004. Apidae. [in:] W. Bogdanowicz, E. Chudzicka, J. Pilipiuk, E. Skibińska (eds.). Fauna of Poland. Characteristics and checklist of species, vol. 1. Muzeum i Instytut Zoologii PAN, Warszawa, 358-362. (in Polish)

80. Banaszak J., Oleksa A. 2006. The nature of Tuchola Pinewoods. [in:] W. JASTRZĘBSKI, J. WoźNY (eds.). Dziedzictwo kulturowe i przyrodnicze Borów Tucholskich. Stan badań i potrzeby badawcze. Materiały z sesji naukowej, 19 listopada 2005 r., Bydgoszcz-Tuchola, 9-23. (in Polish)

81. BanaszaK J., Oleksa A. 2006. The list of insects of "Bory Tucholskie" National Park. [in:] J. BANASZAK, K. ToBOLSKI (eds.). Park Narodowy Bory Tucholskie u progu nowej dekady. Wydawnictwo Uniwersytetu im. Kazimierza Wielkiego, Bydgoszcz, 175-201. (in Polish)

82. BANASZaK J. 2008. The bee fauna (Hymenoptera: Apoidea: Apiformes) of Bydgoszcz. [in] P. INDYKIEWICZ, L. JERZAK, T. BARCZAK (eds.). Fauna miast. Ochronić różnorodność biotyczną w miastach. SAR "Pomorze", Bydgoszcz, 234-245. (in Polish)

83. BANASZAK J. 2008. Diversity of pollinating insects of palace park in Lubostron. [in:] J. BANASZAK, H. RATYŃSKA (eds.). Przyroda parku pałacowego w Lubostroniu. Oficyna Wydawnicza Branta, Bydgoszcz, 113-121. (in Polish)

84. Banaszak J., Twerd L., Kriger R., Motyka E. 2010. The need of active protection of swards for bee fauna conservation. [in:] H. RATYŃSKA, B. WALDON (eds.). Ciepłolubne murawy w Polsce - stan zachowania i perspektywy ochrony. Wydawnictwo Uniwersytetu Kazimierza Wielkiego, Bydgoszcz, 482-492. (in Polish)

85. BANASZAK-CibicKa W., BANASZAK J. 2011. Pollinating insects of cities (Hymenoptera: Apoidea: Apiformes. Part I. Fauna of Poznań in comparison with other polish cities. [in:] P. INDYKIEWICZ, L. JERZAK, J. BÖHNER, B. KAVANAGH (eds.). Urban fauna. Studies of animal biology, ecology and conservation in European cities. Wydawnictwo Uniwersytetu TechnnologicznoPrzyrodniczego, Bydgoszcz, 227-236. 
86. BanaszaK-Cibicka W., BanaszaK J. 2011. Pollinating insects of cities (Hymenoptera: Apoidea: Apiformes. Part II. Fauna of cities in comparison with natural habitats. [in:] P. INDYKIEWICZ, L. JERZAK, J. BÖHNER, B. KAVANAGH (eds.). Urban Fauna. Studies of animal biology, ecology and conservation in European cities. Wydawnictwo Uniwersytetu Technnologiczno-Przyrodniczego, Bydgoszcz, 237-250.

87. BANASZAK J. 2011. Honey bee in forest biocenosis. [in:] W. SKOwroneK (ed.). Bartnictwo. Odrodzenie staropolskiej tradycji, Spała - Świnia Góra, 27-29 sierpnia 2008. Wydawnictwo pokonferencyjne. Gospodarstwo Pasieczne "Sądecki Bartnik", Stróże, 6-22. (in Polish)

88. BANASZAK J., SOBIERAJ A. 2015. A review of significant insect groups of Lower Vistula Region. [in:] J. PAJAূKOWSKI (ed.). Zespół parków krajobrazowych Chełmińskiego i Nadwiślańskiego. Zespół Parków Krajobrazowych Chełmińskiego i Nadwiślańskiego, Toruń, 168-185. (in Polish)

\section{Academic textbooks}

89. BANASZAK J. 1994. A systematic overview of insects. Illustr. by A. ŁĄCKI. Wydawnictwo Uczelniane Wyższej Szkoły Pedagogicznej w Bydgoszczy, Bydgoszcz, 142 pp. (in Polish)

90. BANASZAK J., WiŚNIEWSKi H. 1999. The basics of ecology. Wydawnictwo Uczelniane Wyższej Szkoły Pedagogicznej w Bydgoszczy, Bydgoszcz, 630 pp. (in Polish)

91. BANASZAK J., WiŚNIEWSKI H. 2003. The basics of ecology ( $2^{\text {nd }}$ edition, revised and cocrrected $)$ Wydawnictwo Adam Marszałek, Toruń, 587 pp. (in Polish)

\section{Chapters in academic textbooks}

92. BanASZAK J. 2012. Hymenoptera. [in:] C. BŁaszaK (ed.). Zoologia. Stawonogi. Tom 2. część 2. Wydawnictwo Naukowe PWN, Warszawa, 307-339. (in Polish)

\section{Scientific articles and notes}

93. BANASZAK J. 1969. Contribution to the knowledge of bumblebees (Bombus LATR.) of Bieszczady Mountains. Przegląd Zoologiczny 13(2): 187. (in Polish)

94. BANASZAK J. 1970. Observations on fauna of Hymenoptera nesting in loamy walls of country houses in Great Poland. Badania Fizjograficzne nad Polską Zachodnią ser. B 23: 231-233. (in Polish)

95. BANASZAK J. 1971. Observations on Anthophora parietina FABR. (Hymenoptera, Apoidea). Polskie Pismo Entomologiczne 41(2): 371-381. (in Polish)

96. BANASZAK J. 1971. An interesting case of gynandromorphism in Sphecodes gibbus SCHENCK (Hymenoptera Apoidea). Przegląd Zoologiczny 15(3): 345-346. (in Polish)

97. BANASZAK J. 1971. New sites of a bee Anthophora parietina F. in the vicinity of Poznań. Przyroda Polski Zachodniej 9: 107-111. (in Polish)

98. Banaszak J. 1972. Contribution to the knowledge of Chrysididae of Great Poland. Badania Fizjograficzne nad Polską Zachodnią ser. B 25: 183-184. (in Polish)

99. BANASZAK J. 1973. Hymenoptera Apoidea of the surroundings of Poznan. Badania Fizjograficzne nad Polską Zachodnią ser. B 26: 33-78. (in Polish)

100. BANASZAK J. 1973. The Apoidea of the Wolin National Park. Badania Fizjograficzne nad Polska Zachodnią ser. B 26: 79-88. (in Polish) 
101. BANASZAK J. 1973. Contribution to the knowledge of the Apoidea (Hymenoptera) of Rzeszów environs (Poland). Polskie Pismo Entomologiczne 43(1): 55-60. (in Polish)

102. BANASZAK J. 1973. Solitary bees. Przegląd Zoologiczny 17(1): 54-58. (in Polish)

103. BANASZAK J. 1975. Contribution to bees-fauna (Apoidea, Hymenoptera) of the xerotermic habitats on the lower Vistula. Badania Fizjograficzne nad Polską Zachodnią ser. C 28: 109-122. (in Polish)

104. HRYNIEWIECKA-SZYFTER Z., BANASZAK J. 1975. Histological investigation of the mid-gut bees infected with the spores of Nosema apis ZANDER by individual and mass feeding. Bulletin de la Société des Amis des Sciences et des Lettre de Poznań ser. D 15: 83-86.

105. BANASZAK J. 1975. Records of Chrysididae (Hymenoptera) from southern Poland. Polskie Pismo Entomologiczne 45(1): 23-32. (in Polish)

106. BANASZAK J. 1975. Contribution to the knowledge of bumblebees (Bombus LATR.) and cuckoo bumblebees (Psithyrus LEP.) of Bieszczady Mountains. Przegląd Zoologiczny 19(2): 209-210. (in Polish)

107. BANASZAK J. 1976. Bees (Hymenoptera: Apoidea) of Poznań Botanical Garden. Badania Fizjograficzne nad Polską Zachodnią ser. C 29: 71-85. (in Polish)

108. BŁaszak C., BanaszaK J. 1976. Two species of mites from suborder Mesostigmata new for Poland. Badania Fizjograficzne nad Polską Zachodnią ser. C 29: 163-165. (in Polish)

109. BanaszaK J. 1976. Contribution to bee fauna (Hymenoptera, Apoidea) of Poland I. Polskie Pismo Entomologiczne 46(2): 251-255. (in Polish)

110. BanaszaK J. 1976. Distribution of Bumblebees (Hymenoptera: Apoidea) in Poland. Przegląd Zoologiczny 20(3): 331-335. (in Polish)

111. BANASZAK J. 1976. Chrysididae of Poland in the light of previous studies. Przegląd Zoologiczny 20(4): 440-443. (in Polish)

112. BANASZAK J. 1977. Apoidea (Hymenoptera) of the "Dębina" reserve near Wagrowiec. Badania Fizjograficzne nad Polską Zachodnią ser. C 30: 155-158. (in Polish)

113. BANASZAK J. 1977. Hymenoptera found on oaks in Rogalin near Poznań. Badania Fizjograficzne nad Polską Zachodnią ser. C 30: 109-115. (in Polish)

114. BANASZAK J. 1978. Scolia hirta SCHRANK (Hymenoptera, Scoliidae) in the Lower Vistula region and the distribution of this species in Poland. Przegląd Zoologiczny 22(1): 45-48 (in Polish)

115. BANASZAK J., KASPRZAK K. 1978. An overview of studies on invertebrate in urban areas. Przegląd Zoologiczny 22(3): 239-249. (in Polish)

116. BANASZAK J. 1979. Chironomidae (Diptera) from bottom sediments in various types of water bodies in agricultural areas. Acta Hydrobiologica 21(2): 167-176.

117. BANASZAK J. 1979. Contribution to bee fauna (Hymenoptera, Apoidea) of Poland II. Badania Fizjograficzne nad Polską Zachodnią ser. C 32: 59-68. (in Polish)

118. BANASZAK J. 1979. A new classification of Aculeata (Hymenoptera, Aculeata) by Denis J. Brothers. Przegląd Zoologiczny 23(3): 239-242. (in Polish)

119. BANASZAK J. 1980. Investigations of the fauna associated in bee-hives. Fragmenta Faunistica 25(10): 127-177. (in Polish)

120. BANASZAK J. 1980. Bees (Apoidea, Hymenoptera) of xerothermal habitats in the region of lower Vistula. Fragmenta Faunistica 25(19): 335-360. (in Polish) 
121. BANASZAK J., KASPRZAK K. 1980. Evaluation of occurrence and density of Oligochaeta, Mollusca and Chironomidae in bottom deposits of Lake Zbęchy and in melioration channel within agricultural landscape. Polish Ecological Studies 6(2): 221-245.

122. BANASZAK J. 1980. Studies on methods of censusing the numbers of bees (Hymenoptera, Apoidea). Polish Ecological Studies 6(2): 355-366.

123. Banaszak J., Plewka T. 1981. Apoidea (Hymenoptera) of Kampinoski National Park. Fragmenta Faunistica 25(24): 435-452. (in Polish)

124. BANASZAK J. 1981. Research condition of the bee fauna (Hymenoptera, Apoidea) in Poland. Wiadomości Entomologiczne 2(1-2): 45-50. (in Polish)

125. BANASZAK J. 1981. Research of the bee fauna (Hymenoptera, Apoidea) in the Vistula and San rivers region. Wiadomości Entomologiczne 2(3-4): 115-122. (in Polish)

126. KASPRZAK K., BANASZAK J. 1982. The evaluation of numbers, biomass, and respiration of phytophilous macrofauna in a field drain canal. Acta Hydrobiologica 24(2): 167-173.

127. BanaszaK J. 1982. Bees (Hymenoptera, Apoidea) of the Polish Coast of Baltic Sea. Badania Fizjograficzne nad Polską Zachodnią ser. C 33: 7-38. (in Polish)

128. BANASZAK J. 1982. The occurrence and numbers of bees (Hymenoptera, Apoidea) on winter rape. Badania Fizjograficzne nad Polską Zachodnią ser. C 33: 117-127. (in Polish)

129. BANASZAK J. 1982. Bees (Apoidea, Hymenoptera) of the Great-Poland-Kujavian Lowland. Fragmenta Faunistica 27(7): 75-92. (in Polish)

130. BANASZAK J., WĘGOREK P. 1982. The effects of agricultural chemicals on yield and environment. Kronika Wielkopolski 3/4(29): 128-142. (in Polish)

131. BANASZAK J. 1982. Apoidea (Hymenoptera) of Warsaw and Mazovia. Memorabilia Zoologica 36: $129-142$.

132. BANASZAK J. 1983. Ecology of bees (Apoidea) of agricultural landscape. Polish Ecological Studies 9(4): 421-505.

133. BanaszaK J. 1984. Contribution to bee fauna (Hymenoptera, Apoidea) of Poland III. Badania Fizjograficzne nad Polską Zachodnią ser. C 34:127-147. (in Polish)

134. BANASZAK J. 1984. Anthophorini from Mongolia (Hymenoptera: Apoidea, Anthophoridae). Folia Entomologica Hungarica 45(1): 15-18.

135. BANASZAK J. 1984. The occurrence and numbers of bees (Apoidea) on some cultivated crop plants in the Wielkopolska region (West Poland). Polskie Pismo Entomologiczne 53(4): 623-631. (in Polish)

136. BANASZAK J. 1985. Rural parks as a refuges for pollinating insects. Chrońmy Przyrodę Ojczystą 41(1): 5-9. (in Polish)

137. BANASZAK J. 1984. Density and biomass of benthic Chironomidae (Diptera) in a lake and melioration channel, situated in agricultural landscape. Polskie Archiwum Hydrobiologii 31(4): 353-363.

138. BANASZAK J. 1985. Information on the fauna of bees (Apoidea) of Poland in the unpublished master's theses. Fragmenta Faunistica 29(18): 377-390. (in Polish)

139. BANASZAK J. 1985. Communities of Apoidea in rural environment. Polskie Pismo Entomologiczne 55(1): 115-133. (in Polish)

140. BAnAszaK J., KASPRZAK K. 1985. The zoological collections in Poland - their importance, situation and needs. Przegląd Zoologiczny 29(2): 227-234. (in Polish) 
141. ÖZBEK H., BANASZAK J. 1985. Bees of Anthophorini (Hymenoptera: Apoidea, Anthophoridae) from Eastern Turkey. Türkiye Bitki Koruma Dergisi 9(4): 195-198.

142. RYSZKOWSKI L., BANASZAK J. 1986. The effect of lignite open cast mining on the environment. Biuletyn Komitetu Przestrzennego Zagospodarowania Kraju PAN 129: 14-34. (in Polish)

143. BANASZAK J. 1987. Bees (Hymenoptera, Apoidea) of selected plant associations at Wielkopolski National Park (WNP). Badania Fizjograficzne nad Polską Zachodnią ser. C 35: 5-23. (in Polish)

144. BANASZAK J. 1987. Fauna of wild bees (Hymenoptera, Apoidea) of Wielkopolsko-Kujawska lowland during the last fifty years. Badania Fizjograficzne nad Polską Zachodnią ser. C 36: 67-77. (in Polish)

145. BAnASZaK J., Manole T. 1987. Diversity and density of pollinating insects (Apoidea) in the agricultural landscape of Rumania. Polskie Pismo Entomologiczne 57(4): 747-766.

146. BANASZAK J. 1988. The collection of Aculeata (Hymenoptera) of prof. Edward LuBICZNiEZABITOWSKI. Acta Universitatis Lodzensis, Folia Zoologica et Anthropologica 6: 73-81. (in Polish)

147. BAŁAZY S., BANASZAK J., MichalSKi J. 1989. Studies on xylophagous fauna on the Wielkopolski National Park. V. Hymenoptera-Aculeata. Badania Fizjograficzne nad Polską Zachodnią ser. C 38: 115-121. (in Polish)

148. BanaszaK J. 1989. Phenology of bees (Apoidea) of Central Poland lowlands. Badania Fizjograficzne nad Polską Zachodnią ser. C 38: 123-136. (in Polish)

149. BANASZAK J. 1989. Macrobenthos of small channels and ponds in an agricul-tural landscape. Ecology International Bullletin 17: 53-64.

150. BANASZAK J. 1989. Bees (Apoidea) of moist meadows on the Mazovian Lowland. Memorabilia Zoologica 43: 279-287.

151. BANASZAK J. 1991. A checklist of the bee-species (Apoidea) of Poland with remarks of their taxonomy and zoogeography. Acta Universitatis Lodzensis, Folia Zoologica et Anthropologica 7: 15-66.

152. BANASZAK J. 1991. Bees (Apoidea) of hornbeam-oak and thermophillous oak forests of the Mazovian lowland. Zeszyty Naukowe Wyższej Szkoły Pedagogicznej w Bydgoszczy, Studia Przyrodnicze 8: 23-36. (in Polish)

153. BANASZAK J. 1991. The review of methods for estimating the numbers of the bees (Hymenoptera, Apoidea). Wiadomości Entomologiczne 10(2): 113-119. (in Polish)

154. BANASZAK J. 1992. Strategy for conservation of wild bees in an agricultural landscape Agriculture, Ecosystems \& Environment 40: 179-192.

155. BANASZAK J., KASPRZAK K. 1991. The problems of economy in rural areas of Poland. Marco Cavallo - Rivista quadrimestrale di scienze dell' educazione 3: 19-36.

156. BANASZAK J., RATYŃSKA H. 1992. Forest islands in agricultural landscape - refuges and place for ecological studies. Chrońmy Przyrodę Ojczystą 48(6): 87-92. (in Polish)

157. BANASZAK J., ORTIZ-SANChEZ F.J. 1993. Nuevas aportaciones al conocimiento de la tribu Eucerini en el sureste de Espańa (Hymenoptera: Anthophoridae). Boletín de la Asociación españiola de Entomología 17(2): 263-274.

158. BANASZAK J., CIERZNIAK T. 1994. Spatial and temporal differentiation of bees (Apoidea) in the forests of Wielkopolski National Park, Western Poland. Acta Universitatis Lodzensis, Folia zoologica 2: 3-28. 
159. BAnaszak J., Cierzniak T., SzYMAŃSki R. 1994. Influence of colour of Moericke traps on numbers and diversity of collected bees (Apoidea, Hymenoptera). Acta Universitatis Lodzensis, Folia zoologica 2: 29-35.

160. BANASZAK J., RASMONT P. 1994. Eucera Scopoli nouvelles pour la France (Hymenoptera, Anthophorinae). Butlletin de la Société entomologique de France 99(2): 165-168.

161. BANASZAK J. 1994. Contribution to the biology and ecology of Andrena (Andrena) fulva (MủLLER, 1766) (Hymenoptera, Apoidea). Polskie Pismo Entomologiczne 63(1-2): 169-182.

162. BANASZAK J., CIERZNIAK T. 1994. Estimate density and diversity of Apoidea in steppe reserve "Zbocze Płutowskie" on the lower Vistula river. Polskie Pismo Entomologiczne 63(3-4): 319-336.

163. BANASZAK J., RASmont P. 1994. Occurrence and distribution of the subgenus Bombus LAtreille sensu stricto in Poland (Hymenoptera, Apoidea). Polskie Pismo Entomologiczne 63(3-4): 337-356.

164. BAnASZAK J., Kochanowski A. 1994. Records of Chrysididae (Hymenoptera) from Western Poland. Zeszyty Naukowe Wyższej Szkoły Pedagogicznej w Bydgoszczy, Studia Przyrodnicze 10: 7-24.

165. BANASZAK J., CiERZNiAK T. 1994. The effect of neighbouring environments and the acreage of the winter rapeseed plantations on the diversity and density of Apoidea (Hymenoptera). Zeszyty Naukowe Wyższej Szkoły Pedagogicznej w Bydgoszczy, Studia Przyrodnicze 10: 25-38.

166. BANASZAK J., KASPRZAK K. 1994. Fauna resources of small water reservoirs and small rivers. Zeszyty Naukowe Wyższej Szkoły Pedagogicznej w Bydgoszczy, Studia Przyrodnicze 10: 123-162. (in Polish)

167. BANASZAK J. 1995. Old buildings as refuges for Hymenoptera. Chrońmy Przyrodę Ojczystą 51(4): 94-97. (in Polish)

168. BANASZAK J., CIERZNIAK T. 1995. Economical effect of the pollination of alfalfa and red clover by honey bees in Poland. Rastenievdni nauki 32(6): 84-87. (in Bulgarian)

169. BANASZAK J 1995. Present and prognosticated fauna of bees of the housing estate Białołęa Dworska, Warsaw (Hymenoptera, Apoidea). Zeszyty Naukowe Wyższej Szkoły Pedagogicznej w Bydgoszczy, Studia Przyrodnicze 11: 51-63. (in Polish)

170. BANASZAK J. 1995. Communities of Apoidea (Hymenoptera) in rural parks. Zeszyty Naukowe Wyższej Szkoły Pedagogicznej w Bydgoszczy, Studia Przyrodnicze 11: 65-75. (in Polish)

171. BANASZAK J., IZDEBSKA B. 1995. The ecological aspect of localization and quality of green areas using the example of Bydgoszcz. Zeszyty Naukowe Wyższej Szkoły Pedagogicznej w Bydgoszczy, Studia Przyrodnicze 11: 117-125. (in Polish)

172. Banaszak J., Cierzniak T., Kaczmarek S., Manole T., Pilacińska B., RatyŃSKa H., Szwed W., WIŚNIEWSKI H. 1996. Biodiversity of forest islands in an agricultural landscape. Bulletin of the Polish Academy of Sciences. Biological Sciences 44(1-2): 111-119.

173. BANASZAK J. 1996. More on the species conservation of wild bees (Hymenoptera, Apoidea). Chrońmy Przyrodę Ojczystą 52(1): 73-77. (in Polish)

174. BanaszaK J. 1996. The import of bumblebees to Poland - advantages and threats. Chrońmy Przyrodę Ojczystą 52(4): 110-116. (in Polish)

175. BanaszaK J., KrzysztofiaK A. 1996. Hylaeus pfankuchi (AlfKen, 1919) - a new wild bee species for Poland (Hymenoptera: Apoidea, Colletidae). Przegląd Zoologiczny 40(1-2): 77-78. (in Polish) 
176. BANASZAK J. 1996. Introductory research results of natural resources of pollinating insects of Lednica Landscape Park. Studia Lednickie 4: 495-498. (in Polish)

177. BANASZAK J. 1996. Variability in density of bumblebees in Europe (Hymenoptera: Apoidea: Bombus LATR.). Polskie Pismo Entomologiczne 65(1): 21-32.

178. BanAszaK J., KRZYSZTofiaK A. 1996. The Natural Wild Bee Resources (Apoidea, Hymenoptera) of the Wigry National Park. Polskie Pismo Entomologiczne 65(1): 33-51.

179. Banaszak J., Cierzniak T., Kaczmarek S., Kozacki L., Manole T., Pilacińska B., Ratyńska H., SZWED W., WIŚNIEWSKI H. 1996. Preliminary investigations on biocenoses of forest islands in an agricultural landscape. Zeszyty Naukowe Wyższej Szkoły Pedagogicznej w Bydgoszczy, Studia Przyrodnicze 12: 45-74.

180. BANASZAK J. 1996. Insects of economic importance or about economic entomology. Zeszyty Naukowe Wyższej Szkoły Pedagogicznej w Bydgoszczy, Studia Przyrodnicze 12: 121-149. (in Polish)

181. BANASZAK J. 1997. Local changes in the population of wild bees. I. Changes in the fauna ten years later. Ochrona Przyrody 54: 119-130.

182. Banaszak J. Beekman M., Felicioli A., Hedtke Ch., Krell R., Kwak M., Pinzautti M., Ruijter de A., Smeekens Ch., Steffan-Dewenter I., Williams I., Wittmann D. 1997. Competition between honeybees and other bee species. Report of a workshop. Ambrosiushoeve, Hilvarenbeek, the Netherlands, 28 and 29 November 1997: 1-27.

183. BanaszaK J. 2000. Contribution to bee fauna (Hymenoptera, Apoidea) of Poland. IV. Acta Universitatis Lodzensis, Folia zoolologica 4: 25-28.

184. BANASZAK J. 2000. A checklist of the bee species (Hymenoptera, Apoidea) of Poland, with remarks on their taxonomy and zoogeography: revised version. Fragmenta Faunistica 43(14): 135-193.

185. BANASZAK J., CIERZNIAK T. 2000. An attempt at determination of honeybee colonies required for pollination of natural plant communities in Poland. Pszczelnicze Zeszyty Naukowe 44: 159-173.

186. BANASZAK J. 2000. Research of entomofauna of Lednica Landscape Park. Introductory reports. Studia Lednickie 6: 417-422. (in Polish)

187. BanaszaK J., CierzniaK T. 2000. Assessment of the degree of threat and possibilities of insect protection in agroecosystems. Wiadomości Entomologiczne 18(Supl. 2): 73-94. (in Polish)

188. Banaszak J., Czechowska W., Czechowski W., Garbarczyk H., Sawoniewicz J., WiŚNIOWSKI B. 2000. Threats and perspectives of protection of Hymenoptera. Wiadomości Entomologiczne 18(Supl. 2): 177-211. (in Polish)

189. Romasenko L. P., BANASZAK J. 2002. Notes on the specific status of Chalicodoma saussurei (RADOSZKOWSKI, 1874) (Hymenoptera: Apoidea: Megachilidae). Genus 13(3): 397-404.

190. Banaszak J., Wendzonka J. 2002. Bees (Hymenoptera: Apoidea) of the Bory Tucholskie National Park (NW Poland). Polskie Pismo Entomologiczne 71(4): 327-350.

191. BanaszaK J. 2003. "Góry Pieprzowe" Hills in the vicinity of Sandomierz (SE Poland) as the European refuge of xerotermic bees (Hymenoptera: Apoidea). Polskie Pismo Entomologiczne 72(2): 111-130.

192. BANASZAK J., CieRZNiaK T., RATYŃSKA H. 2003. Local changes in populations of wild bees (Hymenoptera: Apoidea): 20 years later. Polskie Pismo Entomologiczne 72(3): 261-282. 
193. BAnaszak J., RATYŃSka H., BAnaszaK W.A. 2004. Proposed "Folusz" Nature Reserve near Szubin (in Poland) as a refuge of thermophilous plant cover and the fauna of the superfamilies Apoidea and Scolioidea (Hymenoptera, Aculeata). Badania Fizjograficzne nad Polskia Zachodnią ser. C 50: 101-132. (in Polish)

194. Banaszak J., Buszko J., Czachorowski S., CZechowska W., Hebda G., Liana A., Pawłowski J., SZEPTYCKi A., TROJAn P., WĘGIEREK P. 2004. A review of inventory research on insects in the national parks of Poland. Wiadomości Entomologiczne 23(Supl. 2): 5-56. (in Polish)

195. BANASZAK J. 2005. Polish nature in the hands of amateurs. Chrońmy Przyrodę Ojczystą 61(4): 83-87. (in Polish)

196. Romasenko L., BANMASZAK J., CierzniaK T. 2005. Redescription of Andrena (Graecandrena) schwarzi WARNCKE, 1975 and A. (G.) walishanovi OSYTSHNJUK, 1994 (Hymenoptera: Apoidea: Andrenidae). Genus 16(1): 119-128.

197. Cierzniak T., RATyŃSka H., BANASZAK J., KACZMAReK L. 2005. Influence of strict protection on xerothermic grassland and bee fauna on the esker near the Lake Budzyńskie (Wielkopolski National Park). Przegląd Przyrodniczy 16(3-4): 53-83. (in Polish)

198. BANASZAK J., SOŁTYK D. 2005. Rare Wild bee Xylocopa valga GeRSTAECKER, 1872 in Ojcowski National Park (Hymenoptera: Apoidea). Przegląd Zoologiczny 49(3-4): 141-143. (in Polish)

199. Banaszak J., Piotrowski W. 2005. Two very rare Polish bee species: Xylocopa valga GERSTAECKER and Xylocopa violacea (L.) in the Polesie National Park. Wiadomości Entomologiczne 24(2): 77-80. (in Polish)

200. BANASZAK J., CiERZNiaK T., KRIGER R., WENDZONKA J. 2006. Bees of xerothermic swards in the lower Vistula valley: diversity and zoogeographic analyses (Hymenoptera: Apoidea: Apiformes). Polskie Pismo Entomologiczne 75(1): 105-154.

201. BANASZAK J. 2006. Bees (Hymenoptera: Apiformes) in the Narew National Park. Polskie Pismo Entomologiczne 75(4): 511-537.

202. BANASZAK J. 2006. Contribution to bee fauna (Hymenoptera: Apiformes) of Poland. V. Wiadomości Entomologiczne 25(2): 97-103. (in Polish)

203. BANASZAK J. 2006. Entomological research and insects protection in Poland and current juridical and organizational situation. Wiadomości Entomologiczne 25(Supl. 2): 9-16. (in Polish)

204. BanaszaK J., KowalczyK J.K. 2007. Notes on bees (Hymenoptera: Apoidea: Apiformes) of central Poland. Fragmenta Faunistica 50(1): 1-18.

205. BanaszaK J., Motyka E. 2007. Diversity of bumblebee (Bombus LATREILle, 1802) and cuckoobumblebee (Psithyrus LEPELETIER, 1833) species some nature reserves in northern Poland. Parki Narodowe i Rezerwaty Przyrody 26(2): 75-92. (in Polish)

206. BANASZAK J. MielCZAREK Ł., NOwAK C. 2008. New localities of solitary bee Xylocopa violacea (LinNaeus, 1758) (Hymenoptera: Apiformes) in Poland. Wiadomości Entomologiczne 27(1): 37-38. (in Polish)

207. BANASZAK J. 2008. Major trends and challenges of entomology in the $21^{\text {st }}$ century in Poland. Wiadomości Entomologiczne 27(Supl.): 59-76. (in Polish)

208. BanaszaK J. 2009. Pollinating insects (Hymenoptera: Apoidea, Apiformes) as an example of changes in fauna. Fragmenta Faunistica 52(2): 105-123.

209. BANASZAK J. Twerd L. 2009. Historical and current records of Scolia hirta SCHRANK, 1781 (Hymenoptera: Scoliidae) in Poland. Polish Journal of Entomology 78(1): 101-110. 
210. Banaszak J., MiŁkowski M., Mikolajczak K. 2009. New localities of two very rare hymenopterans in Poland: Parnopes grandior (PALLAS, 1771) and Xylocopa valga GerstaeCKer, 1872 (Aculeata: Chrysididae and Apidae). Polish Journal of Entomology 78(1): 111-113.

211. Banaszak J., Kriger R., Cierzniak T. 2009. Bees (Hymenoptera, Apiformes) of the Drawa National Park. Polish Journal of Entomology 78(2): 135-156.

212. BanaszaK J., Jaroszewicz B. 2009. Bees of the Białowieża National Park and adjacent areas, NE Poland (Hymenoptera: Apidea, Apiformes). Polish Journal of Entomology 78(2): 281-313.

213. BANASZaK J., Twerd L. 2010. High number of cuckoo wasps (Hymenoptera: Chrysididae) in areas directly affected by lime and sodium industry. Polish Journal of Entomology 79(3): 291-305.

214. BANASZAK J. 2009. The following localization of solitary bee Xylocopa violacea (LiNNAEUS, 1758) (Hymenoptera: Apoidea) in Poland. Wiadomości Entomologiczne 28(1): 63-64. (in Polish)

215. BANASZAK J. 2010. Bees of the Masurian Landscape Park: diversity and ecology (Hymenoptera: Apoidea, Apiformes). Polish Journal of Entomology 79(1): 25-53.

216. BANASZAK J. 2010. Bees of the Wolin National Park and adjacent areas, NE Poland (Hymenoptera: Apidea, Apiformes). Polish Journal of Entomology 79(1): 55-76.

217. BANASZAK J. 2010. The persistence of and changes in a bee fauna over the last century: case of Wielkopolska-Kujawy Lowland in western Poland (Hymenoptera: Apoidea, Apiformes). Polish Journal of Entomology 79(4): 367-409.

218. BANASZAK J. 2010. A review of studies on the Hymenoptera of Polish mountains with particular reference to pollinating insects. Wiadomości Entomologiczne 29(Supl.): 7-26. (in Polish)

219. BANASZAK J., SZEFER P. 2012. Lasioglossum pallens (BRULlÉ 1832) (Hymenoptera: Apiformes: Halictidae) - first certain record of occurrence in Poland. Wiadomości Entomologiczne 31(3): 178-180. (in Polish)

220. BANASZAK J. 2012. Honey bee on Polish land. Studia Lednickie 11: 93-113. (in Polish)

221. BANASZAK J., RATYŃSKA H., SZEFER P. 2013. Diversity of bees and associated plant cover. The case of "Ostrów Małe Rudy" habitat island in the Noteć River valley near Bydgoszcz (Hymenoptera, Apoidea, Apiformes). Badania Fizjograficzne 54: 29-56.

222. BANASZAK J., TwERD L., TwERD J. 2013. Results of the preliminary studies of bee fauna diversity in the steppe reserve "Gipsowa Gora" in Opole province. Chrońmy Przyrodę Ojczystą 69(5): 422-429. (in Polish)

223. Twerd L., BANASZAK J. 2013. Conservation problems of bee fauna (Hymenoptera: Apoidea, Apiformes) in reserve "Góra Gipsowa". Inżynieria Ekologiczna 33: 147-155. (in Polish)

224. BANASZAK J., MOtYKA E., SZCZEPKO K. 2013. Andrena florivaga Eversmann, 1852 (Hymenoptera: Apoidea: Andrenidae) - a new bee species of the genus Andrena in Poland. Journal of Apicultural Science 57(1): 45-50.

225. Banaszak J., Szefer P. 2013. Bees (Hymenoptera: Apoidea) of Sępopolska Flatland. Cz. I. Species diversity. Wiadomości Entomologiczne 32(3) 185-201. (in Polish)

226. BANASZAK J., Twerd L. 2013. The Natura 2000 network - a tool or a problem in insect conservation efforts? The case of bees (Apoidea, Apiformes). Wiadomości Entomologiczne 32(Supl.): 53-64. (in Polish)

227. BanaszaK J., Dochrova B. 2014. Bees (Hymenoptera, Apoidea, Apiformes) in the agricultural landscape of Bulgaria: species diversity. Journal of Apicultural Science 58(1): 29-49. 
228. BANASZAK J., BANASZAK-CIBICKA W., SZEFER P. 2014. Guidelines on sampling intensity of bees (Hymenoptera: Apoidea: Apiformes). Journal of Insect Conservation 18(4): 651-656.

229. BANASZAK J., SzEFER P. 2014. Diversity partitioning of wild bee assemblages (Hymenoptera: Apoidea, Apiformes) and species preferences for three types of refuge habitats in an agricultural landscape in Poland. Polish Journal of Entomology 83(3): 235-257.

230. BANASZAK J., RATYŃSKA H. 2014. Local changes in communities of wild bees (Hymenoptera: Apoidea, Apiformes): 30 years later. Polish Journal of Entomology 83(4): 325-351.

231. Szefer P., BAnaszaK J. 2014. Pollinating insects (Hymenoptera: Apoidea, Apiformes) of Sępopolska Flatland. Part II. Community structure. Wiadomości Entomologiczne 33(1): 50-60. (in Polish)

232. Banaszak J., Twerd L. 2015. Bees of forest "Dziki Ostrów" near Bydgoszcz. Chrońmy Przyrodę Ojczystą 71(1): 53-60. (in Polish)

233. BANASzaK J., Szefer P., DochKova B. 2015. Relationships between bees (Hymenoptera: Apoidea: Apiformes) and flowers in the Bulgarian agricultural landscape. Polish Journal of Entomology 84(2): 101-126.

234. Banaszak J., Sobieraj-Betlińska A. 2016. Bees (Hymenoptera: Apoidea, Apiformes) of the Kujawy Lakeland (central Poland). Fragmenta Faunistica 59(1): 7-27. (in Polish)

235. BANASZAK J., RATYŃSKA H. 2016. Natural islands and habitat islands as refuges of vegetation cover and wild bees. The case of the Lednica Landscape Park in western Poland. Polish Journal of Entomology 85(1): 27-92.

236. BANASZAK J. 2016. Distribution and ecology of bees on the Polish Baltic coast (Hymenoptera, Apoidea, Apiformes). Polish Journal of Entomology 85(3): 269-309.

\section{Congress communications}

237. KOSTECKI R., BANASZAK J. 1973. Preliminary investigations of the fauna associated in bee-hives. [in:] C. Meletiv (ed.). The $\mathrm{XXV}^{\text {th }}$ International Congress of Apiculture, Buenos Aires, Argentina, October 14-20, 1973. Apimondiae, Bucharest, 377-379.

238. BANASZAK J. 1974. Introductory studies of the accompanying fauna of beehives. [in:] Biuletyn V Zjazdu Polskiego Towarzystwa Nauk Weterynaryjnych, Olsztyn 12-14 września 1974. Akademia Rolniczo-Techniczna w Olsztynie, Olsztyn, 490. (in Polish)

239. Banaszak J. 1976. Bees (Hym., Apoidea) of Pomerania against a background of zoogeographic relationships. [in:] XXXV Zjazd Polskiego Towarzystwa Entomologicznego, Gdańsk, 12-15 września 1976 r., pp. 49-53. (in Polish)

240. BANASZAK J. 1979. 200 years of studies on bee fauna (Hymenoptera) in Poland. [in:] XII Zjazd Polskiego Towarzystwa Zoologicznego, Poznań, 3-6 IX 1979, Streszczenia referatów. Polskie Towarzystwo Zoologiczne, Poznań, 8-9. (in Polish)

241. BANASZAK J. 1979. Occurrence and density of Chironomidae from bottom sediments in water bodies in an agricultural landscape. [in:] XI Zjazd Hydrobiologów Polskich w Lodzi, 5-8 września 1979, Streszczenia komunikatów. Polskie Towarzystwo Hydrobiologiczne, Instytut Biologii Środowiskowej Uniwersytetu Łódzkiego, Łódź, 6. (in Polish)

242. BANASZAK J. 1980. Research condition of the bee fauna (Hymenoptera, Apoidea) in Poland. [in:] XXXVII Zjazd Polskiego Towarzystwa Entomologicznego, Kraków, 22-24 IX 1980. Polskie Towarzystwo Entomologiczne, Zarząd Główny oraz Oddział w Krakowie, Kraków, 4. (in Polish) 
243. BANASZAK J. 1983. Pattern of distribution of Apoidea in agricultural landscape. [in:] Proceedings of the $\mathrm{V}^{\text {th }}$ International Symposium on Pollinatio, Versailles (France), 27-30 septembre 1983. Institut national de la recherche agronomique, Paris, 33.

244. BANASZAK J. 1986. Impact of agricultural landscape structure on diversity and density of pollination insects. [in:] J. MissonNIER, L. RYSZKOWSKI (eds.). Impacts de la structure des paysages agricoles sur la protection des-cultures: colloque France-Pologne, Poznań (Pologne), 9-14 septembre 1985. Institut national de la recherche agronomique, Paris, 75-84.

245. BANASZAK J. 1987. Factors compensating the effect of human pressure on pollinating insect fauna in agricultural landscape. [in:] Streszczenia referatów. XIV Zjazd Polskiego Towarzystwa Zoologicznego, Szczecin 17-19 IX 1987. Akademia Rolnicza w Szczecinie, Szczecin, 11. (in Polish)

246. Banaszak J., Cierzniak T. 1991. The effect of surroundings and field size of oilseed rape on diversity and density of Apoidea. [in:] XXVIII Naukowa Konferencja Pszczelarska, Puławy, 9-10 IV 1991 r, Streszczenia referatów. Oddział Pszczelarski ISK, PTN, Puławy, 1. (in Polish)

247. BANASZAK J., CIERZNIAK T. 1993. Vertical and temporal heterogeneity of honey bee in forest ecosystems. [in:] XXX Naukowa Konfferencja Pszczelarska, 16-17 III 1993, Puławy. Oddział Pszczelarski ISK, PTN, Puławy, 2-3. (in Polish)

248. Banaszak J., Cierzniak T., Kozacki L., Pitacińska B., Ratyńska H., Szwed W. 1993. The conservation significance of forest islands for flora and fauna in agricultural landscape. [in:] Abstracts book. IALE Congress "Agricultural landscapes in Europe”, Rennes, France, 6-10 june 1993, 180.

249. BANASZAK J. 1994. New data of occurrence and distribution of subgenus Bombus LATREILLE s. str. in Poland. [in:] XXXI Naukowa Konferencja Pszczelarska, Streszczenia referatów. Oddział Pszczelarski ISK, PTN, Puławy, Puławy, 3. (in Polish)

250. BANASZAK J., CiERZNIAK T. 1994. Quantitative effects of honey bee and wild bees pollination on cultivar plant. [in:] XXXI Naukowa Konferencja Pszczelarska, Streszczenia referatów. Oddział Pszczelarski ISK, PTN, Puławy, Puławy, 4-6. (in Polish)

251. BANASZAK J., CierzNiaK T. 1994. Evaluation of natural resources of wild bees in Poland. [in:] XXXI Naukowa Konferencja Pszczelarska, Streszczenia referatów. Oddział Pszczelarski ISK, PTN, Puławy, Puławy, 7-8. (in Polish)

252. BANASZAK J.1994. Variability of density of bumblebees in Europe. [in:] A. LENOIR, G. ARNOLD, M. LePAGE (eds.). Les insectes Sociaux. $12^{\text {th }}$ Congres of the Internationalä Union for the Study of Social Insects Paris, Sorbonne, 21-27 August 1994. Université Paris Nord, Paris, 333.

253. BanaszaK J., CierzniaK T. 1994. Changes of diversity and density of bees (Apoidea) in temperate deciduous forests. [in:] J.H. TALLIS, H.J. NoRMAN, R.A. BENTON (eds.). INTECOL Machester 1994: progress to meet the challenge of environmental change - proceedings of the VI International Congress of Ecology, 21 to 26 August 1994. Department of Environmental Biology, University of Machester, Machester, 29.

254. Banaszak J., Cierzniak T., Kaczmarek S., Kozacki L., Manole T., Pilacińska B., Ratyńska H., SzwED W. 1994. [in:] J.H. TALlis, H.J. NoRman, R.A. BENTON (eds.). INTECOL Machester 1994: progress to meet the challenge of environmental change - proceedings of the VI International Congress of Ecology, 21 to 26 August 1994. Department of Environmental Biology, University of Machester, Machester, 81.

255. BANASZAK J. 2001. Research of pollinating insects in Poland against a background of other European countries. [in:] L. BuchHolz, J. NowAcki (eds.). Materiały 44. Zjazdu Polskiego Towarzystwa Entomologicznego. Spała, 14.-16. IX. 2001. Polskie Towarzystwo Entomologiczne, Poznań, 3-8. (in Polish) 
256. BANASZAK J. 2001. Apidology research in Institute of Biology and Environmental Protection of Bydgoszcz Academy. [in:] L. BuchHolz, J. Nowacki (eds.). Materiały 44. Zjazdu Polskiego Towarzystwa Entomologicznego. Spała, 14.-16. IX. 2001. Polskie Towarzystwo Entomologiczne, Poznań, 17-18. (in Polish)

257. BANASZAK J. 2001. Ecological importance of marginal habitats for bee populations in the agricultural landscape. [in:] Proceedings of the 2001 Berlin Meeting of the European Sections of the International Union for the Study of Social Insects. Sept. 25-29. Free University of Berlin, Berlin, 130.

258. BANASZAK J. 2002. Activity of Institute of Biology and Environmental Protection of Bydgoszcz Academy for science and Kuyavian-Pomeranian region. [in:] E. JuTROwSKA (ed.). Światowy Dzień Ochrony Środowiska "Dajmy Szansę Ziemi", Bydgoszcz, Materiały konferencyjne, 97-105. (in Polish)

259. BANASZAK J. 2007. Diversity of Wild bees in Poland: research and changes in fauna. [in:] P. SIENKIEWICZ (red.). XLVI Zjazd Polskiego Towarzystwa Entomologicznego, V Konferencja Naukowa Ochrona owadów w Polsce: Różnorodność biologiczna owadów Polski - aktualny stan badań oraz perspektywy jej ochrony. Poznań, 20 - 22 IX 2007. Polskie Towarzystwo Entomologiczne, Poznań, 3-4. (in Polish)

260. BANASZAK J. 2008. The newest trends and challenges in entomology of XXI century. [in:] J. Nowacki, L. BuchHolz, P. SiEnkiewicz (eds.). Jubileuszowy zjazd Polskiego Towarzystwa Entomologicznego z okazji 85-lecia, Ogólnopolska Konferencja Naukowa "Społeczna i naukowa rola ruchu amatorskiego w Polsce", Bystre k. Baligrodu - Lwów, 26-29 czerwca 2008. Polskie Towarzystwo Entomologiczne, Poznań, 10-11. (in Polish)

261. BANASZAK J. 2010. A review of research on Hymenoptera of Poland with special regard to pollinating research. [in:] J. NowACKI, P. SIENKIEWICZ (eds.). XLVIII Zjazd Polskiego Towarzystwa Entomologicznego oraz Ogólnopolska Konferencja Naukowa z cyklu "Ochrona owadów w Polsce" nt. "Entomofauna górska - stan aktualny oraz perspektywy jej ochrony w Polsce", Huta Szklana, 16-19 września 2010 r. Polskie Towarzystwo Entomologiczne, Poznań, 9-10. (in Polish)

262. BANASZAK J., Twerd L. 2013. The Natura 2000 network - a tool or a problem in insect conservation efforts? The case of bees (Apoidea, Apiformes) - summary. [in:] L. BuchHolz, P. SIENkIEwICZ (eds.). XLIX Zjazd Polskiego Towarzystwa Entomologicznego oraz VII Ogólnopolska Konferencja Naukowa z cyklu "Ochrona owadów w Polsce" nt.: "Projekt Natura 2000 jako narzędzie ochrony owadów w Polsce. Stan aktualny i perspektywy na przyszłość", Puszczykowo, 12-15 września 2013 r. Polskie Towarzystwo Entomologiczne, Poznań, 10-11. (in Polish)

263. SobierAJ-BETLiŃSKA A., BANASZAK J. 2016. Forest islands in an agricultural landscape and forests as refuges for bees. [in:] L. BuchHOlZ, M. BunALSKI, P. SiENKIEWICZ (eds.). 50. Zjazd Polskiego Towarzystwa Entomologicznego oraz VIII Ogólnopolska Konferencja Naukowa z cyklu "Ochrona owadów w Polsce" nt. "Entomofauna leśna - różnorodność, ochrona i kierunki badań", Sękocin Stary, 16-18 września 2016 r. Polskie Towarzystwo Entomologiczne, Poznań, 18. (in Polish)

\section{Popularised scientific books}

264. BANASZAK J. 1992. Apples as heavy as lead: talks about ecology. Fundacja "Warta", Poznań, 63 pp. (in Polish)

265. BANASZAK J. 1998. The role of honey bees in natural environment. Polski Związek Pszczelarski, Warszawa, 59 pp. (in Polish) 
266. BanaszaK J., NAdOlski J. 2001. Aculeata and stings. Guide for everyone. Wydawnictwo Akademii Bydgoskiej im. Kazimierza Wielkiego, Bydgoszcz, 90 pp. (in Polish)

267. BANASZAK J. 2003. The insect world of Narew National Park. Narwiański PN, Kurowo, 28 pp. (in Polish)

268. BANASZAK J. 2003. The insect world of National Park "Bory Tucholskie". Park Narodowy "Bory Tucholskie", Charzykowy, 60 pp. (in Polish)

\section{Other popularised scientific publications}

269. BANASZAK J. 1971. Roadsides and balks are necessary for bees. Hasło Ogrodnicze 6: 22. (in Polish)

270. BANASZAK J. 1971. Protection of bees against bee louse invasion. Pszczelarstwo 1971(6): 9-10. (in Polish)

271. BANASZAK J. 1972. Jean Henri FABRE. Wszechświat 71(5): 130-131. (in Polish)

272. BANASZAK J. 1973. The symbiosis of bees and flowers. Wszechświat 74(12): 314-315. (in Polish)

273. BANASZAK J. 1976. Roadsides and balks as refuges for bees. Poradnik Gospodarski 1976(11): 17. (in Polish)

274. Banaszak J., Czechowski W., Pisarski B., Skibińska E. 1978. Social insects in the urban environment, Kosmos ser. A 2(151): 173-180. (in Polish)

275. BANASZAK J. 1978. The importance of bees (Apoidea) as pollinators of crop plants. Wiadomości Ekologiczne 24(3): 225-248. (in Polish)

276. BANASZAK J. 1978. Insect fauna of oaks in Rogalin. Wszechświat 79(5): 123-125. (in Polish)

277. KASPRZAK K., BANASZAK J. 1978. Fauna of the urban areas. Wszechświat 79(12): 305-307. (Polish)

278. BanASZAK J. 1980. Not only harmful insects. Poradnik Gospodarki 1980(6): 6. (in Polish)

279. BANASZAK J. 1980. Bees as pollinators of oilseed crops. Poradnik Gospodarski 1980(13/14): 26. (in Polish)

280. BANASZAK J. 1980. Out of concern for agricultural environment. Poradnik Gospodarski 1980(16): 6. (in Polish)

281. BanaszaK J. 1980. Bumblebees. Przyroda Polska 1980(7/8): 37. (in Polish)

282. BANASZAK J. 1981. The harmful effect of gricultural use of roadsides. Poradnik Gospodarski 1981(20): 4. (in Polish)

283. BANASZAK J. 1981. Underestimated components of agricultural landscape. Przyroda Polska 1981(7/8): 19. (in Polish)

284. BANASZAK J., KASPRZAK K. 1982. Problems with management of rural areas. Kosmos ser. A 31(1-2): 57-69. (in Polish)

285. BANASZAK J. 1984. For the rescue of nature. Nurt 1984(9): 5-7. (in Polish)

286. BANASZAK J. 1984. Forage base of honey bee (I). Poradnik Gospodarski 1984(6): 24. (in Polish)

287. BANASZAK J. 1984. Forage base of honey bee (II). Poradnik Gospodarski 1984(7): 19-20. (in Polish)

288. BANASZAK J. 1984. Forage base of honey bee (III). Poradnik Gospodarski 1984(8): 24. (in Polish) 
289. BANASZAK J. 1985. Talks about ecology: Oikos means home. Nurt 1985(10): 5-6. (Also in: Promocje Pomorskie 11: 16-17, 1996). (in Polish)

290. BANASZAK J. 1986. Bees and plant pollination. Problemy 4: 17-21. (in Polish)

291. BANASZAK J. 1986. Talks about ecology: against ourselves. Nurt 1986(2): 5. (in Polish)

292. BANASZAK J. 1986. Talks about ecology: strategy of our salvage. Nurt 1986(6): 11. (in Polish)

293. BANASZAK J. 1986. Talks about ecology: human, crowd, aggression. Nurt 1986(10): 2-3. (in Polish)

294. BANASZAK J. 1986. Nature of Wielkopolska region - condition and conservation perspectives. Kalendarz Wielkopolski 1987: 133-137. (in Polish)

295. BANASZAK J. 1987. Bee research in Poland - past and present. Melissa 2: 12-16.

296. BANASZAK J. 1987. Talks about ecology: forest was before us. Nurt 1987(4): 3. (in Polish)

297. BANASZAK J. 1987. Talks about ecology: Professor Adam WodZICZKO. Nurt 1987(5): 3-4. (in Polish)

298. BANASZAK J. 1987. Talks about ecology: nuclear power station and bats. Nurt 1987(9): 3-4. (in Polish)

299. BANASZAK J. 1987. A history of Chrysidid work in Poland. Sphecos 15: 9-12.

300. BANASZAK J. 1988. Talks about ecology: the ill lungs of the city. Nurt 1988(5): 3-4. (in Polish)

301. BanaszaK J. 1989. Pollinating insects conservation strategy in Poland. Kosmos 38(3): 363-374. (in Polish)

302. BANASZAK J., KASPRZAK K. 1989. Directions for surface water use and conservation for hydrobiological resources protection. Kosmos 38(3): 375-384. (in Polish)

303. BANASZAK J. 1989. Talks about ecology: threatened rural areas. Nurt 1989(4): 2-3. (in Polish)

304. BANASZAK J. 1989. Talks about ecology: the outcome of smoky chimneys. Nurt 1989(7): 2. (in Polish)

305. BANASZAK J. 1990. An appeal for the legal protection of all species of wild Apoidea (Hymenoptera). Chrońmy Przyrodę Ojczystą 46(1): 5-8. (in Polish)

306. BANASZaK J. 1992. Underestimated components of landscape. Przyroda Polska 1992(9): 12. (in Polish)

307. BANASZAK J., IZDEBSKA B. 1994. Effect of environmental pollution on wild Apoidea, honey bee and its products. Kosmos 43(2): 285-302. (in Polish)

308. BANASZAK J. 1994. On the need of ecological education of society. Zeszyty Naukowe Wyższej Szkoły Pedagogicznej w Bydgoszczy, Studia Przyrodnicze 11: 5-11. (Also in: E. FrYCKOwSKI (ed.), Przemówienia rektorskie i wykłady inauguracyjne, Wydawnictwo Uczelniane Wyższej Szkoły Pedagogicznej w Bydgoszczy, Bydgoszcz 1995, 267-276). (in Polish)

309. BANASZAK J. 1994. Condition and conservation of natural environment. [in:] K. MATUSIAK (ed.) Wielka Księga Miasta Poznania. Dom Wydawniczy “Koziołki Poznańskie”, Poznań, 623-626. (in Polish)

310. BANASZAK J., CIERZNIAK T. 1995. Economical effects of arable crops pollination by honey bee and wild bees (Apoidea). Kosmos 44(1): 47-61. (in Polish)

311. BANASZAK J., RATYŃSKA H., SZWED W. 1995. Forest islands as an important element of the landscape. Kosmos 44(1): 63-70. (in Polish)

312. BANASZAK J. 1995. Poznań area of ecological threat. Koziołki Poznańskie 1(17): 6. (in Polish) 
313. BANASZAK J. 1996. The first architectural and natural monument. Lednica 11-12: 10-11. (in Polish)

314. BANASZAK J., CIERZNIAK T. 1996. Economic effects of pollination of chosen cultivated plants. Pszczelarstwo 1996(3): 5-6. (in Polish)

315. BANASZAK J. 1996. The economic importance of bees. [in:] J. BONDARCZUK (ed.). Wojewódzki Dzień Pszczelarza Więcbork 1996. Jubileusz 50-lecia Koła Pszczelarzy w Więcborku, Więcbork, 15-16. (in Polish)

316. BANASZAK J. 1998. Old country cottage - a place of Hymenoptera insects living. Studia Lednickie 5: 293-305. (in Polish)

317. BanaszaK J. 1998. Apoidea. [in:] J. PrabucKi (ed.). Pszczelnictwo. Wydawnictwo Promocyjne „Albatros”, Szczecin, 25-64. (in Polish)

318. BANASZAK J. 2000. Food competition between honey bee and other bee species. Pszczelarstwo 2000(4): 5. (in Polish)

319. BanaszaK J. 2001. Island landscape. Przegląd Ekologiczny Pomorza i Kujaw 11: 4-5. (in Polish)

320. BanaszaK J. Cierzniak T. 2002. How many bee families can live in Poland? Pszczelarstwo 2002(2): 5. (in Polish)

321. BANASZAK J. 2005. Pros and cons of environment and nature protection. [in:] Ochrona przyrody w województwie kujawsko-pomorskim. V Interdyscyplarne Forum Naukowe dla młodzieży szkół ponadgimnazjalnych. Urząd Wojewódzki, Bydgoszcz, 8. (in Polish)

322. BanaszaK J. 2009. First bees. Przegląd Pszczelarski 17(4): 10-11. (in Polish)

323. BANASZAK J. 2010. Bees and forest. The honey bee versus the postglacial history of forests in Poland: a book trailer. Przegląd Pszczelarski 18(1): 42-45. (in Polish)

324. BANASZAK J. 2013. Encyclopedia of beekeeping. Systematic of bees (22 articles) [in:] J. WILDE (ed.) Encyklopedia pszczelarska. PWRiL, Warszawa. (in Polish)

\section{Other papers}

325. BANASZAK J., KASPRZAK K. 1980. The economy of rural areas and environmental protection. Chrońmy Przyrodę Ojczystą 36(4): 45-47. (in Polish)

326. BANASZAK J., KARG J., KASPRZAK K. 1980. The economy of rural areas and environmental protection (Szczecin, 29-30 XI 1978). Wiadomości Ekologiczne 26(1): 73-78. (in Polish)

327. BANASZAK J. 1980. Scientific session "Problems of management of the Vistula and shaping of its landscape" (Kraków, Pieskowa Skała, 29-30 X 1979 r.). Wiadomości Ekologiczne 26(3): 345-349. (in Polish)

328. BanASZAK J. 1981. Landscape condition in Poland. Scientific session (Kraków, 23-24 V 1980 r.). Wiadomości Ekologiczne 27(1): 92-94. (in Polish)

329. BANASZAK J., KASPRZAK K., TRUSZKOWSKI J. 1981. Building development of non-urbanized areas. Seminary (Wrocław, 29-31 V 1980 r.). Wiadomości Ekologiczne 27(1): 95-97. (in Polish)

330. BANASZAK J., KASPRZAK K. 1981. Ecological, medical and sociological conditions of shaping the environmentally valuable areas. Conference (Dymaczewo k. Poznania, 15-16 X 1980). Wiadomości Ekologiczne 27(3): 302-305. (in Polish)

331. BANASZAK J., KASPRZAK K. 1981. Problems of Wielkopolska National Park as a subject of deliberations of Commission of Environmental Protection of Poznań Department PAS (3 III 1981 r). Wiadomości Ekologiczne 27(4): 401-403. (in Polish) 
332. BANASZAK J. 1983. Working meeting of interdepartmental problem research groups MR II/23 "Environmental basis of agriculture development and management in rural areas" (Poznań, 9 II, 3-4 III, 17 III 1982 r.). Wiadomości Ekologiczne 29(1): 78-81. (in Polish)

333. KASPRZAK K., BANASZAK J. 1984. Environmental protection in agriculture. Zesz. Probl. Post. Nauk Roln., zeszyt 228 (1979). Chrońmy Przyrodę Ojczystą 40(1): 85-87). (in Polish)

334. BANASZAK J. 1997. Department of Biology and Environmental Protection WSP. Promocje Pomorskie 3: 11-12. (in Polish)

335. BanaszaK J. 1997. The way to the Bydgoszcz University. Promocje Pomorskie 10: 2-3. (in Polish)

336. Banaszak J. 1997. From the activity of the Department of Biology and Environment Protection, the Pedagogical University of Bydgoszcz. Zeszyty Naukowe Wyższej Szkoły Pedagogicznej w Bydgoszczy, Studia Przyrodnicze 13: 159-175. (in Polish)

337. Banaszak J., Michalik S., Fijal J., Kosior A. 1998. Effect of succession of non-forest communities on Apoidea in the Skołczanka forest-steppe reserve. Pradnik. Prace i Materiały Muzeum im. Prof. Władysława Szafera 11-12: 223-250. (in Polish)

338. BANASZAK J. 1999. Briefly about the previous rector term. [in:] M. GuZEK (ed.). Na drodze do uniwersytetu. Materiały i dokumenty kadencji rektorskiej WSP 1996-1999. Wydawnictwo Uczelniane Wyższej Szkoły Pedagogicznej w Bydgoszczy, Bydgoszcz, 11-14. (in Polish)

339. [BANASZAK J. 1999]. The speech of Rector of WSP in Bydgoszcz, prof. Józef BANASZAK at the inauguration of academic year on 3 October 1996. [in:] M. GUZEK (ed.). Na drodze do uniwersytetu. Materiały i dokumenty kadencji rektorskiej WSP 1996-1999. (ed.). Wydawnictwo Uczelniane Wyższej Szkoły Pedagogicznej w Bydgoszczy, Bydgoszcz, 17-22. (in Polish)

340. [BANASZAK J. 1999]. The speech of Rector of WSP in Bydgoszcz, prof. Józef BANASZAK at the inauguration of academic year on 1 October 1997. [in:] M. GuZEK (ed.). Na drodze do uniwersytetu. Materiały i dokumenty kadencji rektorskiej WSP 1996-1999. Wydawnictwo Uczelniane Wyższej Szkoły Pedagogicznej w Bydgoszczy, Bydgoszcz, 23-28. (in Polish)

341. [BANASZAK J. 1999]. The speech of Rector of WSP in Bydgoszcz, prof. Józef BANASZAK at the inauguration of academic year on 5 October 1998. [in:] M. GuZEK (ed.). Na drodze do uniwersytetu. Materiały i dokumenty kadencji rektorskiej WSP 1996-1999. Wydawnictwo Uczelniane Wyższej Szkoły Pedagogicznej w Bydgoszczy, Bydgoszcz, 29-32. (in Polish)

342. BANASZAK J., WIŚNIEWSKI H. 1999. Organizational elaboration of planned university in Bydgoszcz. [in:] M. GuzeK (ed.). Na drodze do uniwersytetu. Materiały i dokumenty kadencji rektorskiej WSP 1996-1999. Wydawnictwo Uczelniane Wyższej Szkoły Pedagogicznej w Bydgoszczy, Bydgoszcz, 80-114. (in Polish)

343. BANASZAK J. 2000. Institute of Biology and Environmental Protection. Promocje Pomorskie 2000(2): 17-18. (in Polish)

344. BanasZaK J. 2001. Preface to the second edition. [in:] Z. JAŚKOWSKI (ed.). Bydgoski Instytut Rolniczy w niepodległej Polsce 1920-1939. Dział Poligrafii Akademii Bydgoskiej, Bydgoszcz, 9-10. (in Polish)

345. BANASZAK J. 2002. My journey to the entomological Holy Land. Notatki Entomologiczne 3: 6-11. (in Polish)

346. BANASZAK J. 2005. A diary of a journey (1). Kwartalnik Akademicki 1(9): 48-52. (in Polish)

347. BANASZAK J. 2005. A diary of a journey (2). Kwartalnik Akademicki 2(10): 40-43. (in Polish)

348. BANASZAK J., SzARK M. 2010. Faculty of Natural Sciences. [in:] W. JASTRZĘBSKI (ed.). 40 lat uczelni 1969-2009. WSN-WSP-AB-UKW. Wydawnictwo Uniwersytetu Kazimierza Wielkiego, Bydgoszcz, 323-326. (in Polish) 
349. BANASZAK J. 2010. Institute of Biology. [in:] W. JASTRZĘBSKI (ed.). 40 lat uczelni 1969-2009. WSN-WSP-AB-UKW. Wydawnictwo Uniwersytetu Kazimierza Wielkiego, Bydgoszcz, 327-349. (in Polish)

350. BANASZAK J. 2011. "Wierzenica" Professors' Club. Kalendarz Bydgoski 44: 137-140. (in Polish)

351. BANASZAK J. 2014. The history of Department - Institute - Faculty. [in:] H. RATYŃSKA (ed.). 20 lat Biologii w Bydgoszczy. Wydawnictwo Uniwersytetu Kazimierza Wielkiego, Bydgoszcz, 25-37. (in Polish)

352. BANASZAK J. 2014. Institute of Environmental Biology. [in:] H. RATYŃSKA (ed.). 20 lat Biologii w Bydgoszczy. Wydawnictwo Uniwersytetu Kazimierza Wielkiego, Bydgoszcz, 38-64. (in Polish)

\section{ARTS, LITERATURE, PHILOSOPHY, HISTORY OF SCIENCE \\ Monographs}

353. BANASZAK J., BZDAWKA U. 1991. Authors of the Wielkopolska region. Informator. Wojewódzka Biblioteka Publiczna, Poznań, 166 pp. (in Polish)

354. BANASZAK J. 2003. Institute of Biology and Environmental Protection. Education and research activities. Akademia Bydgoska im. Kazimierza Wielkiego, Wydz. Matematyki, Techniki i Nauk Przyrodniczych. Wydawnictwo Akademii Bydgoskiej im. Kazimierza Wielkiego, Bydgoszcz, 24 pp. (in Polish)

355. BanaszaK J., Trzeciakowski W. (eds.) 2004. Walk along the philosophers' Alley: August CIESZKOWSKI and his intellectual legacy. Wydawnictwo Akademii Bydgoskiej im. Kazimierza Wielkiego, Bydgoszcz, 85 pp. (in Polish)

356. Banaszak J., Trzeciakowski W. (eds.) 2005. Remembering MiŁosz... is it a closed epoch? Wydawnictwo Akademii Bydgoskiej im. Kazimierza Wielkiego, Bydgoszcz, 104 pp. (in Polish)

357. Banaszak J., Trzeciakowski W. (eds.) 2007. With August CieszKowsKi in the background: five years of the "Wierzenica" Professors' Club (2002-2007). Urząd Miejski w Bydgoszczy, Wydział Kultury i Promocji Miasta, Bydgoszcz, 47 pp. (in Polish)

358. BANASZAK J., TRZECIAKOWSKI W. (eds.) 2008. Choices and consequences. Religious inspirations of LiEBERT, BĄK, BrandstaetTer and WojtYŁa. Wydawnictwo Uniwersytetu Kazimierza Wielkiego, Bydgoszcz, 123 pp. (in Polish)

359. BAnAszak J. (ed.) 2012. What after August CieszKowski? A view after 120 years. Wydawnictwo Uniwersytetu Przyrodniczego w Poznaniu, Poznań, 133 pp. (in Polish)

360. BANASZAK J. 2014. Not only Wierzenica: About Agust CIESZKOWSKI on the $200^{\text {th }}$ anniversary of his birth. Uniwersytetu Przyrodniczego w Poznaniu, Poznań, 186 pp. (in Polish)

361. Banaszak J., Lebioda D.T., StRycka E. (eds.) 2014. On the wings of thoughts... August CIESZKOWSKI and the Wierzenica land in poetry. Wydawnictwo Uniwersytetu Przyrodniczego w Poznaniu, Poznań, 127 pp. (in Polish)

362. BANASZAK J. 2014. August CIESZKOWSKI on the $200^{\text {th }}$ anniversary of his birth. Wydawnictwo Uniwersytetu Przyrodniczego w Poznaniu, Poznań, 186 pp. (in Polish)

\section{Other publications}

363. BANASZAK J. 1984. Naturalists of Poznań - the past and the present. Nurt 1984(6): 5-7. (in Polish) 
364. Banaszak J., BzDawka U. 1990. Polish Authors' Society. Bibliographical guidebook, Wojewódzka Biblioteka Publiczna w Poznaniu 4: 36-40. (in Polish)

365. BANASZAK J. 1991. Professor Aleksander KoRnAK. Zeszyty Naukowe Wyższej Szkoły Pedagogicznej w Bydgoszczy, Studia Przyrodnicze 7: I-V, VI-XI. (in Polish)

366. BANASZAK J. 1995. Botanist from Dziekanowice - priest Franciszek WAWRZYNIAK. Lednica 9-10(26-27): 9-10. (in Polish)

367. BANASZAK J. 1995. Visiting hermitage of Jean-Henri FABRE. Wszechświat 96(9): 223-225. (in Polish)

368. BANASZAK J. 1996. In memory of Jerzy ŁACHOWSKI (1925-1982). Zeszyty Naukowe Wyższej Szkoły Pedagogicznej w Bydgoszczy, Studia Przyrodnicze 12: 5-15. (in Polish)

369. BANASZAK J. 1997. Relations of Profesor Adam WODZICZKO with the Pomerania and Bydgoszcz. Zeszyty Naukowe Wyższej Szkoły Pedagogicznej w Bydgoszczy, Studia Przyrodnicze 13: 139-153. (in Polish)

370. Banaszak J., Gershenson Z., Romasenko L. 1999. Anna Zakharovna Osytshnuuk (19261998). Obituary. Polskie Pismo Entomologiczne 68(1): 107-109.

371. BanAsZaK J. 1999. Włodzimierz KulmatyCKi (1895-1939). Promocje Pomorskie 1999(10): 9. (in Polish)

372. BanaszaK J. 2001. Dzierżoń Jan. [in:] M. BunAlSKi, J.J. LiPA, J. Nowacki (eds.). Almanach entomologów polskich XX wieku. Wiadomości Entomologiczne 20(Supl.): 58-59. (in Polish)

373. BanaszaK J. 2001. JakubSKi Antoni Władysław. [in:] M. Bunalski, J.J. Lipa, J. Nowacki (eds.). Almanach entomologów polskich XX wieku. Wiadomości Entomologiczne 20(Supl.): 76. (in Polish)

374. BANASZAK J. 2001. SZULCZEWSKi Jerzy Wojciech [in:] M. BUNALSKI, J.J. LIPA, J. NowackI (eds.). Almanach entomologów polskich XX wieku. Wiadomości Entomologiczne 20(Supl.): 199. (in Polish)

375. BANASZAK J. 2001. Stanisław FAJFER - visual artist and theatre initiator. Wierzeniczenia 2001 (6): 16-17. (in Polish)

376. BANASZAK J. 2002. Dr Włodzimierz KULMATYCKI - ichthyologist and pioneer in water contamination research (on the 100. anniversary of his birth). Przegląd Rybacki 2002(2): 32-37. (in Polish)

377. Banaszak J., Trzeciakowski W. 2003. "Wierzenica” Professors' Club: Bydgoszcz' scientific and social phenomenon. Kwartalnik Akademicki 2: 54-55. (in Polish)

378. BANASZAK J. 2004. 100 years of environmental expeditions to Wierzenica. [in:] J. BANASZAK, W. TRZeCiakowsKi (eds.). Spacer aleją Filozofów. August CieSZKOwSKi i jego intelektualna spuścizna. Wydawnictwo Akademii Bydgoskiej im. Kazimierza Wielkiego, Bydgoszcz, 53-74. (in Polish)

379. BANASZAK J. 2004. The sapient and beautiful harmony of nature: August CIESZKOwSKI about natural sciences. [in:] A. KUROWSKI, E.J. BUCZYŃSKA, W. BUCZYŃSKI (eds.). Duch wielki, serce złote: August CIESZKOwSKI - jego intelektualna i materialna spuścizna. Urząd Miasta i Gminy Swarzędz, Swarzędz, 31-40. (in Polish)

380. BANASZAK J. 2005. To people with passion with acknowledgement for "Wierzeniczenia". Letter to the editorial board. Wierzeniczenia 2005(3): 30-31. (in Polish)

381. Banaszak J., Trzeciakowski W. 2005. An introduction to the discussion on MiŁosz. [in:] J. BANASZAK, W. TRZECIAKOWSKI (eds.). Wspominając MıŁosZA.. Czy zamknięta epoka? Wydawnictwo Akademii Bydgoskiej im. Kazimierza Wielkiego, Bydgoszcz, 7-10. (in Polish) 
382. BANASZAK J. 2007. In memory of Professor Tomasz CIERZNiaK (1961-2006). Wiadomości Entomologiczne 26(1): 49-56. (in Polish)

383. BAnASZAK J. 2008. In memory of Professor Yurij A. PesenKo (1944-2007). Wiadomości Entomologiczne 27(2): 105-112.

384. BANASZAK J. 2008. Confession of faith and religious inspirations in poetry. [in:] J. BANASZAK, W. TRZeCiaKowski (eds.). Wybory i konsekwencje. Religijne inspiracje LieberTA, BĄKA, BRANDSTAETTERA i WoJTYŁY. Wydawnictwo Uniwersytetu Kazimierza Wielkiego, Bydgoszcz, 7-10. (in Polish)

385. BANASZAK J. 2009. Professor Przemysław Trojan on the $80^{\text {th }}$ anniversary of his birth. Wiadomości Entomologiczne 28(4): 201-207. (in Polish)

386. BANASZAK J. 2009. It seems that so recently... [Wierzeniczenia - the 10th anniversary]. Wierzeniczenia 2009(6): 23-24. (in Polish)

387. BANASZAK J. 2010. Statuette of August CieSZKowSKi for Ewa and Włodzimierz BuCZyński. Wierzeniczenia 2010(7): 3-4. (in Polish)

388. BANASZAK J. 2012. About August CIESZKOWSKI, philosophy and Wierzenica - invitation to read the book. [in:] J. BANASZAK (ed.). Co po Auguście CiESZKowskim? Spojrzenie po 120 latach. Wydawnictwo Uniwersytetu Przyrodniczego w Poznaniu, Poznań, 7-10. (in Polish)

389. BANASZAK J. 2012. August CieszKowski and Wierzenica land in the eyes of naturalist [in:] J. BANASZAK (ed.). Co po Auguście CieszKowskim? Spojrzenie po 120 latach. Wydawnictwo Uniwersytetu Przyrodniczego w Poznaniu, Poznań, 81-97. (in Polish)

390. BANASZAK J. 2013. $100^{\text {th }}$ issue of "Wierzeniczenia" - for people - religion - culture- family. Wierzeniczenia 2013(5): 24-26. (in Polish)

391. BAnAszaK J. 2014. August CIESZKOWSKI and his Wierzenica from deeper perspective. Introduction. [in:] J. BANASZAK (ed.). Nie tylko Wierzenica. O Auguście CIESZKOWSKIM w dwusetną rocznicę urodzin. Wydawnictwo Uniwersytetu Przyrrodniczego w Poznaniu, Poznań, 5-7. (in Polish)

392. BANASZAK J. 2014. The naturalist view of August CiESZKOwSKI and Wierzenica land. [in:] J. BANASZAK (ed.). Nie tylko Wierzenica. O Auguście CieszKowskim w dwusetną rocznicę urodzin. Wydawnictwo Uniwersytetu Przyrrodniczego w Poznaniu, Poznań, 9-26. (in Polish)

393. BANASZAK J. 2015. The fulfilled artist: Michał KubiaK the recipient of Medal of Jerzy SulimaKAMIŃSKI. Temat 18-20: 110-111. (in Polish)

394. BanaszaK J. 2016. In Memoriam: Profesor Przemysław Trojan (1929-2015). Polish Journal of Entomology 85(1): 3-12.

395. BANASZAK J. 2016. Charles D. MichenER, world famous entomologist and bee expert, has passed on. Polish Journal of Entomology 85(2): 177-180.

396. BanaszaK J. 2016. Andrzej SzWALbe about the efforts to establish the university in Bydgoszcz. [in:] M. Снамот, S. Pastuszewski. (eds.). Andrzej Szwalbe i jego dziedzictwo. Zbiór studiów tom 1. Stowarzyszenie im. Andrzeja Szwalbego "Dziedzictwo", Bydgoszcz, 119-124. (in Polish)

\section{POETRY AND PROSE}

397. BanaszaK J. 2004. Admiration for time. Galeria Autorska Jan Kaja, Jacek Soliński, Bydgoszcz, 47 pp. (in Polish)

398. BANASZAK J. 2007. Like an unsent letter. Wierzeniczenia 2007(6): 4-6. (in Polish) 
399. BANASZAK J. 2008. Time has not passed by: memories of a naturalist. Oficyna Wydawnicza Branta, Bydgoszcz, 349 pp. (in Polish)

400. BANASZAK J. 2011. I chose Bydgoszcz: diaries of 1989-2009. Bydgoski Dom Wydawniczy „Margrafsen” s.c., Bydgoszcz, 782 pp. (in Polish)

401. BANASZAK J. 2014. Praise of everyday life: diaries of 2009-2013. Związek Literatów Polskich, Oddział Bydgosko-Toruński, Bydgoszcz, 621 pp. (in Polish)

402. BANASZAK J. 2015. Like an unsent letter: old and new poems. Związek Literatów Polskich, Oddział Bydgosko-Toruński, Bydgoszcz, 93 pp. (in Polish)

403. BanaszaK J. 2016. My Poznań: diaries of 1975-1988. Wydawnictwo Poznańskie, Poznań, 470 pp. (in Polish)

404. BANASZAK J. 2016. Poetry - Józef BANASZAK. Nestor 2016(2): 71-72. (in Polish)

Received: 5 December 2016

Accepted: 5 December 2016 